\title{
Palynology, vegetation and climate of the Waikato lowlands, North Island, New Zealand, since $c$. 18,000 years ago
}

\author{
R. M. Newnham*, D. J. Lowe** and J. D. Green**
}

The vegetational and climatic history of the Waikato lowlands during the last c. 18,000 years is inferred from the palynology of sediment cores from Lakes Rotomanuka, Rotokauri, and Okoroire. Intra- and inter-lake correlations were aided by multiple tephra layers interbedded with the lake sediments. The detailed chronological resolution given by these tephra sequences shows that late glacialpost glacial vegetational and climatic changes were nearly simultaneous throughout the Waikato lowlands.

From $c .18,000$ to just before 14,000 radiocarbon years ago, the region remained largely unforested. There were successive peaks of herb and shrub taxa: Gramineae, Phyllocladus, Halocarpus, Coprosma. Tree taxa, mostly Nothofagus and Libocedrus, increased, probably because the harsh climates - windy, relatively dry and $\operatorname{cool}\left(c .4^{\circ} \mathrm{C}\right.$ below present temperatures) - were gradually abating. Tall podocarp trees were rare but not absent from the region.

Reafforestation proceeded rapidly, beginning c. 14,500 years ago soon after thr deposition of Rerewhakaaitu Ash. The earliest forests were dominated by Prumnopitys taxifolia and, until c. 13,000 years ago, the persistence of $N$. menziesit suggests that temperatures may have been as much as $3^{\circ} \mathrm{C}$ colder than present. After that time, $N$. menziesii disappeared and Dacrydium predominated, reflecting a trend towards moister and warmer conditions.

From c. 11,000 years ago the expansion of angiosperms (especially Metrosideros, Nestegis and Ascarina) and tree ferns within Dacrydium-dominated assemblages is consistent with evidence from elsewhere in New Zealand of an early postglacial period of maximum wetness and warmth. However, by c. 8,500 years ago, Ascarina was already declining, perhaps because of increased frostiness or droughtiness, or both. Regular cycles in the Dacrydium pollen curves are interpreted to result from abundant emergent $D$. cupressinum trees being felled by low frequency, high intensity storms.

From $c .5,500$ years ago this drying trend continued as indicated by rarity of Ascarina, increases of Phyllocladus and Agathis, more microscopic charcoal, and decreases of Dacrydium relative to the other tall podocarps. At all three sites Agathis is most prominent after c. 3,000 years ago, reaching maximum levels $c$. 1,000 years ago.

Many tree taxa (most notably Agathis at Lake Rotokauri) were adversely affected by Polynesian burning. The earliest recorded fires were about 800 years ago.

Keywords: palynology, tephrochronology, radiocarbon ages, reafforestation, forest disturbance, human deforestation, late Quaternary palaeoenvironment, Rerewhakaaitu Ash, Waikato lakes, lake sediment cores

\section{INTRODUCTION}

Late Quaternary palynology in New Zealand began in southern South Island (Cranwell and von Post, 1936) and subsequent work generally favoured southern and central sites. The northern North Island received attention only comparatively recently (Harris, 1963; McGlone et al., 1978; McGlone, 1983b; McGlone et al., 1984; Kershaw and Strickland, 1988; Dodson et al., 1988; Enright et al., 1988; Pocknall et al., 1989). Previous

* Department of Geology, University of Auckland, Private Bag, Auckland

** School of Science and Geochronology Research Unit, University of Waikato, Private Bag, Hamilton 


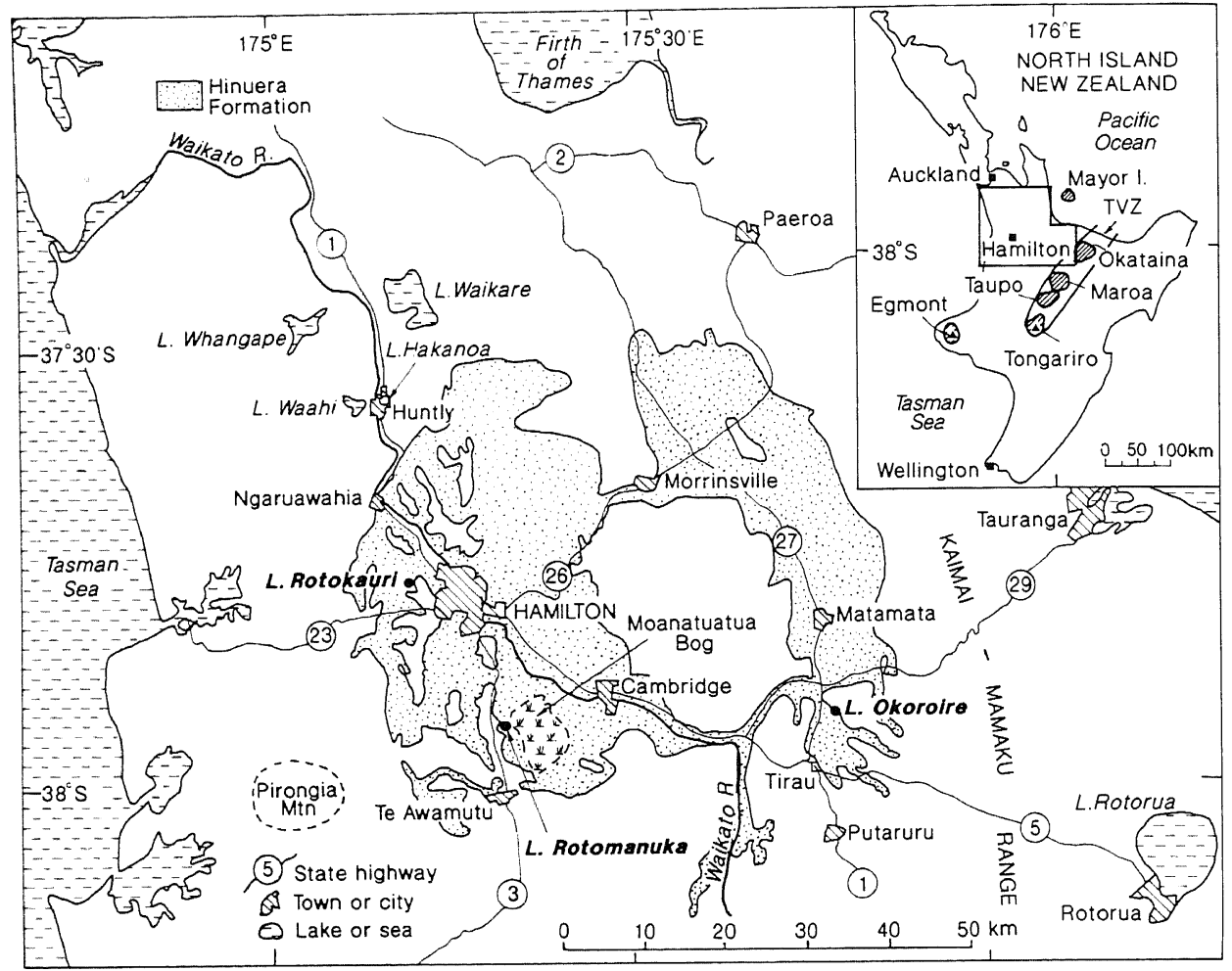

Fig. 1 - Locations of Lakes Rotomanuka, Rotokauri, and Okoroire in the Waikato region, North Island. Inset shows main late Quaternary tephra eruption centres; TVZ = Taupo Volcanic Zone. Distribution of Hinuera Formation (stippled) is after Hume et al. (1975).

investigations in the Waikato region have either lacked age control (Harris, 1963) or span relatively short periods of time (McGlone et al., 1978: 20,000-18,000 years B.P.; McGlone et al., 1984: c 6,000-2,000 years B.P.) [All ages reported and discussed here are conventional radiocarbon ages based on the Libby (old) half life of 5568 years (Hogg et al., 1987)].

We present here the results of an analysis of pollen assemblages in sediment cores from three lakes near latitude $38^{\circ} \mathrm{S}$ in the Waikato lowlands, northern North Island (Fig. 1), which provide a continuous and well-dated record of vegetational history spanning the last c. 18,000 years. The three Waikato riverine lakes-Rotomanuka, Rotokauri, and Okoroire-contain the longest and most complete sequence of dated tephra layers yet investigated in New Zealand lakes and bogs (Lowe, 1988). Such detailed chronologic control permits the construction of continuous time scales for the pollen series as well as the determination of pollen accumulation rates. The lakes are small (4-74 ha) and their sediments are expected to record the deposition of predominantly extralocal and regional (sensu Janssen, 1973) pollen (Jacobson and Bradshaw, 1981). A more comprehensive analysis of the data including discussion of local wetland vegetation changes at each of these sites will be presented elsewhere.

\section{Waikato Vegetation}

Historic

Various evidence indicates that, before human settlement, much of the region was covered in conifer-broadleaf forest. Taylor and Pohlen (1958) suggested from studies of soils that the ranges to the west and east of the Waikato lowlands were probably dominated by broadleaf and podocarp forests, respectively. Lowland soils show evidence of tree overturn, 
and pieces of kauri gum have occasionally been found in them. The isolated relict stands of forest trees (Edmonds and Henshaw, 1984), the presence of stumps and logs buried in peats (Cranwell, 1939, 1953; Gudex, 1963; Lowe, 1985), and pollen analyses of peat profiles (Harris, 1963; McGlone et al., 1984), all point towards extensive forest cover in the recent past.

The Waikato area has been settled for possibly c. 1,000 years or more (Roberton, 1965; Bellwood, 1978; Lowe et al., 1984). The effects of Polynesian settlement on the vegetation were probably substantial and extensive, because the first European settlers in the early nineteenth century found much of the area covered with manuka scrub and fern, with some scattered clumps of forest and, in the wetter parts, swamp and bog communities (Kirk, 1871; Cranwell, 1939).

\section{Modern}

The native vegetation of the Waikato has been discussed in detail by several authors (e.g. Gudex, 1963; Clayton-Greene, 1976, 1978) and McKelvey and Nicholls (1957) classify forests on hilly areas in the west and south of the region as podocarp-angiosperm, with Dacrydium cupressinum and Beilschmiedia tawa listed as prominent species. Nothofagus truncata grows throughout the region, in a range of habitats, most notably on drier ridges where it is often found in association with Agathis australis and Phyllocladus trichomanoides. $N$. fusca and N. menziesii are generally restricted to higher altitudes $(>650 \mathrm{~m})$ in the Kaimai Range (Clayton-Greene, 1978) where there is a well-marked altitudinal zonation of forest ecotones (Jane and Green, 1983). The distribution of $A$. australis may be related in part to soil type and terrain (Clayton-Greene, 1978), but probably also reflects forest clearance patterns (P.J. de Lange, pers. comm., 1988). In the northern Hamilton Basin the presence of kauri stumps and logs in peat swamps (Cranwell, 1939; Gudex, 1963), together with the isolated occurrence of old living kauri in natural environments (Edmonds and Henshaw, 1984; de Lange, 1986, 1989) suggests that there were once extensive tracts of $A$. australis in the lowlands north of latitude $38^{\circ} \mathrm{S}$.

One of three major floristic boundaries first recognised by Cockayne (1910) crosses the Waikato, close to the three sites investigated. A number of northern species, including Agathis australis, Avicennia resinifera, Beilschmiedia taraire and Phebalium nudum are close to their southern boundaries at latitude $38^{\circ} \mathrm{S}$, while southern species are either rare further north (e.g. Libocedrus bidwillii, Nothofagus menziesii), or are found only at the highest altitudes (e.g. Phyllocladus aspleniifolius var alpinus, Halocarpus bidwillii, Podocarpus nivalis).

\section{Climate}

Annual rainfall in the Waikato lowlands usually exceeds $1100 \mathrm{~mm}$ and increases with altitude to over $2500 \mathrm{~mm}$ on Mts Te Aroha and Pirongia (de Lisle, 1967; Maunder, 1974). Soil moisture deficits are recorded on average one year in two, more commonly in the northern Hamilton Basin than in the south. Mean annual temperatures are $c$. $14^{\circ} \mathrm{C}$, with temperatures slightly higher in the east than in the west. Frosts may be recorded in any month, and ground frosts up to 70 or 80 days each year.

\section{Lake Sites}

The three lakes (Fig. 1) originated c. 18,000-16,000 years ago during the final stages of alluvial aggradation of the Hinuera Formation by the ancestral Waikato river (McCraw, 1967; Green and Lowe, 1985; Lowe and Green, 1987). Lake Rotomanuka has an area of c. 14 ha, a maximum depth of $8 \mathrm{~m}$, and lies at $33 \mathrm{~m}$ altitude on the western edge of the large ombrogenous Moanatuatua peat bog. Lake Rotokauri, at altitude $50 \mathrm{~m}$ a.s.l., is 74 ha and has a maximum depth of $4 \mathrm{~m}$. Lake Okoroire is 4 ha with a maximum depth of $2.3 \mathrm{~m}$ and lies at $90 \mathrm{~m}$ a.s.l. These lakes were more extensive in the past, but water tables varied during their history (e.g. Green and Lowe, 1985) and in particular have been lowered during European times by drainage for agriculture. Today they are surrounded by pastoral farmland and the local vegetation has been much modified, although part of the Moanatuatua bog remains as a protected area (see Matheson, 1978). 
L. Rotomanuka

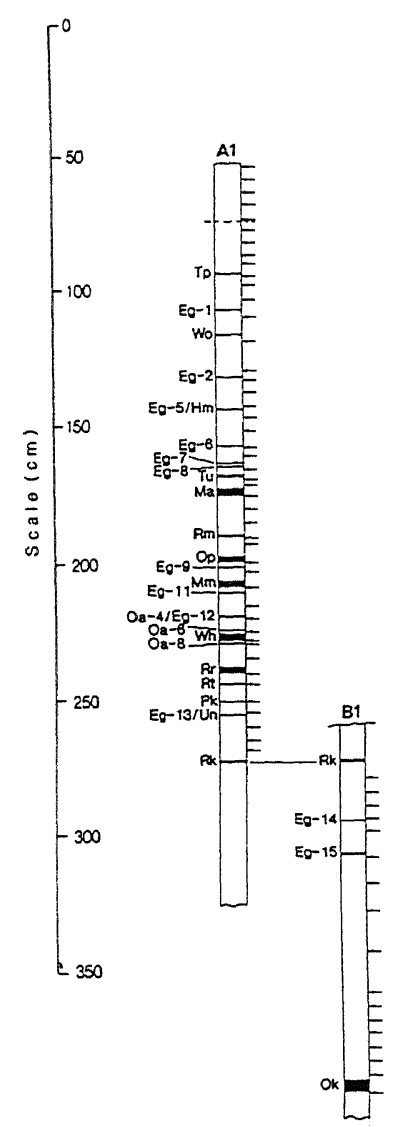

L. Rotokauri<smiles>FC(F)(F)C1CCCCC1</smiles>

L. Okoroire

Fig. 2-Stratigraphic columns of sediment cores extracted at Lakes Rotomanuka, Rotokauri, and Okoroire showing horizons sampled for palynology (arrowed). Abbreviations and radiocarbon ages of the tephra layers are given in Table 1. Numbers prefixcd Wk-are those of the University of Waikato Radiocarbon Dating Laboratory. Wk-659 from Lowe (1988); others, this paper.

\section{METHODS}

\section{Core Extraction}

The sediment cores were taken using Livingstone or Mackereth piston corers operated from the stern of a small boat or barge (Fig. 2; see Green and Lowe, 1985; Kellett, 1985). One core was taken on the peaty shores of Lake Okoroire. Several cores were taken from each lake, and matched with one another using the tephra layers as marker beds (Fig. 2).

\section{Stratigraphy and Chronology of the Cores}

The lakes contain 2.5-4 m of soft, brownish-black to olive-grey, peaty lacustrine muds. Embedded within the lake sediments is a sequence of mainly ash grade tephra layers, ranging in thickness from c. 2-110 mm (Fig. 2). The tephra layers were identified from their mineralogical assemblages and glass and mineral compositions, and their ages determined from multiple radiocarbon dates (Lowe, 1988). These results are summarised in Table 1; more detailed descriptions are available in Lowe (1988:129; see also Hogg et al., 1987). The slow sedimentation rates (c. 0.1-0.3 mm/yr; Fig. 3) reduce the accuracy of the age estimates for tephra deposition because the sediment samples from which 
Table 1-Ages and sources of tephra layers identified in sediment cores from Lakes Rotomanuka, Okoroire, or Rotokauri (after Lowe, 1988).

\begin{tabular}{|c|c|c|}
\hline Tephra name and symbol & $\begin{array}{c}\text { Source } \\
\text { (see Fig. 1) }\end{array}$ & $\begin{array}{c}\text { Age } \\
\text { (years B.P.) } \\
\end{array}$ \\
\hline Taupo Pumice (Tp) & Taupo & 1,800 \\
\hline Mapara Tephra (Mp) & Taupo & 2,200 \\
\hline Egmont $-1(\mathrm{Eg}-1)^{1}$ & Egmont & 2,500 \\
\hline Whakaipo Tephra (Wo) & Taupo & 2,800 \\
\hline Egmont - $2(\mathrm{Eg}-2)$ & Egmont & 3,700 \\
\hline Egmont - $3(\mathrm{Eg}-3)$ & Egmont & 3.750 \\
\hline Egmont - 4 (Eg-4) & Egmont & 4,100 \\
\hline Egmont - $5(\mathrm{Eg}-5)$ & Egmont & 4,400 \\
\hline Hinemaiaia Tephra (Hm) & Taupo & 4,500 \\
\hline Whakatane Ash (Wk) & Okataina & 4,800 \\
\hline Egmont - $6(\mathrm{Eg}-6)$ & Egmont & 5,250 \\
\hline Egmont - 7 (Eg-7) & Egmont & 5,850 \\
\hline Egmont - $8(\mathrm{Eg}-8)$ & Egmont & 5,900 \\
\hline Tuhua Tephra (Tu) & Mayor Is & 6,200 \\
\hline Mamaku Ash (Ma) & Okataina & 7,000 \\
\hline Rotoma Ash (Rm) & Okataina & 8,500 \\
\hline Opepe Tephra (Op) & Taupo & 8,900 \\
\hline Egmont - $9(\mathrm{Eg}-9)$ & Egmont & 9,300 \\
\hline Egmont - $10(\mathrm{Eg}-10)$ & Egmont & 9,600 \\
\hline Mangamate Tephra $(\mathrm{Mm})^{2}$ & Tongariro & 9,950 \\
\hline Okupata Tephra $(\mathrm{Oa}-1)^{3}$ & Tongariro & 10,100 \\
\hline Egmont - 11 (Eg-11) & Egmont & 10,100 \\
\hline Okupata Tephra (Óa-2) & Tongariro & 10,500 \\
\hline Okupata Tephra (Oa-3) & Tongariro & 10,800 \\
\hline Okupata Tephra (Oa-4) & Tongariro & 11,050 \\
\hline Egmont-12 (Eg-12) & Egmont & 11,050 \\
\hline Okupata Tephra (Oa-5) & Tongariro & 11,200 \\
\hline Okupata Tephra (Oa-6) & Tongariro & 11,700 \\
\hline Okupata Tephra (Oa-7) & Tongariro & 12,100 \\
\hline Waiohau Ash (Wh) & Okataina & 12,200 \\
\hline Okupata Tephra (Óa-8) & Tongariro & 12,700 \\
\hline uncorrelated (un) & Tongariro & 13,100 \\
\hline Rotorua Ash (Rr) & Okataina & 13,300 \\
\hline Rotoaira Lapilli (Rt) & Tongariro & 13,700 \\
\hline Puketarata Ash (Pk) & Maroa & 14,000 \\
\hline Egmont - 13 (Eg-13) & Egmont & 14,500 \\
\hline uncorrelated (un) & Mayor Is & 14,500 \\
\hline Rerewhakaaitu Ásh (Rk) & Okataina & 14,700 \\
\hline Egmont-14 (Eg-14) & Egmont & 15,000 \\
\hline Egmont - $15(\mathrm{Eg}-15)$ & Egmont & 15,500 \\
\hline Okareka Ash (Ok) & Okataina & 18,000 \\
\hline
\end{tabular}

1 Informally named Egmont derived tephras

2 Possibly Te Rato Lapilli member

3 Members of Okupata Tephra Formation informally designated Oa-1 to Oa-8.

N.B.: Some tephra deposits are more reliably dated than others; in most cases, the 1 std. dev. dating laboratory counting errors associated with each tephra are within 100-200 years (see Lowe, 1988).

radiocarbon dates were obtained (adjacent to each tephra layer) may represent a time span of 100-200 years (Lowe, 1988). However, this potential reduction in accuracy is partly offset by obtaining a stratigraphic succession of ages in the cores from several sites, and by the availability (via correlation) of dates on many of the tephra deposits in other environments (e.g. Hogg et al., 1987; Froggatt and Lowe, in press). Five additional radiocarbon ages (three from L. Rotokauri, two from $\mathrm{L}$. Okoroire) were obtained using a low-level liquid scintillation spectrometer (Quantulus), and are given in Fig. 2. 


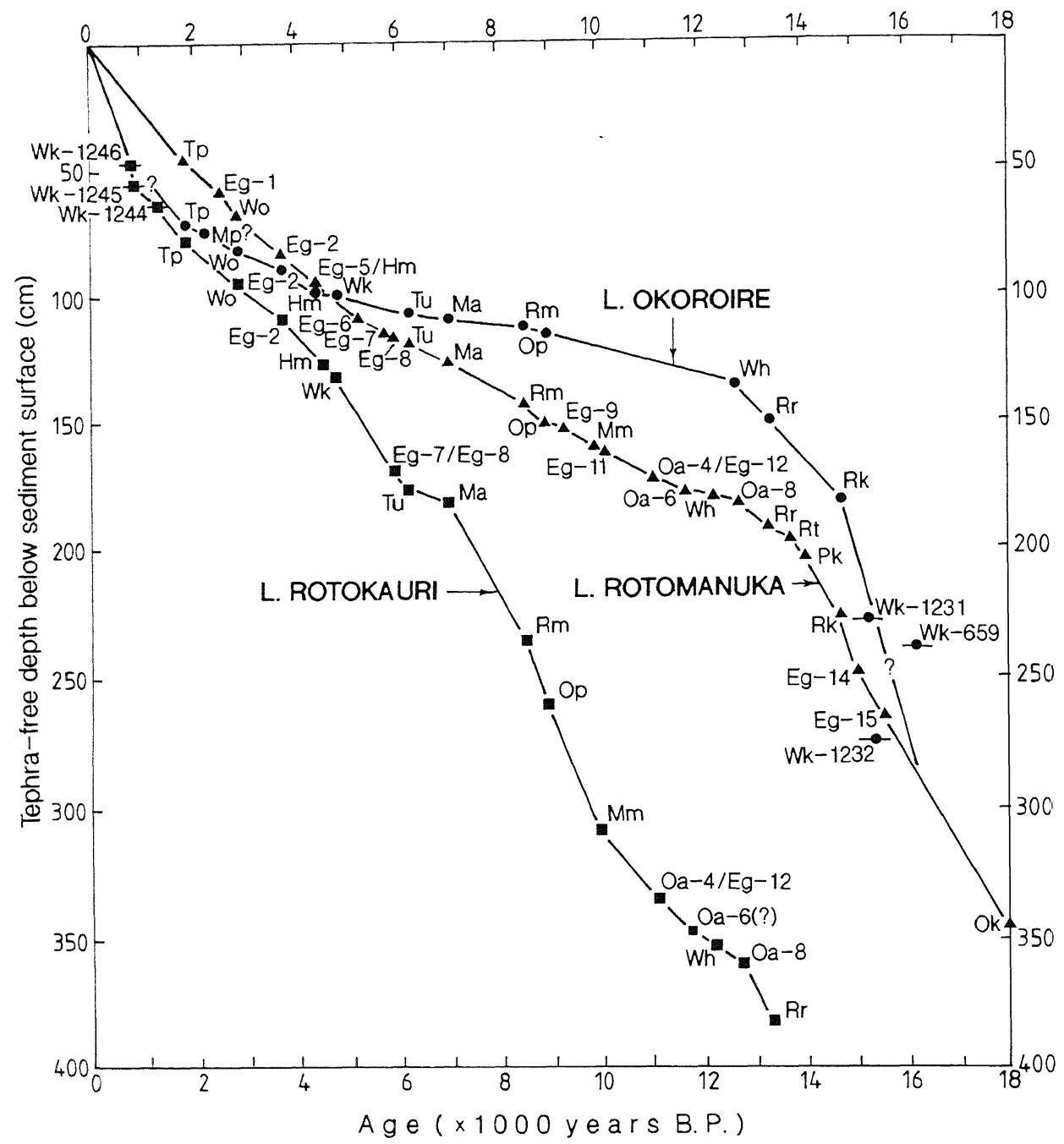

Fig. 3-Sediment depth-age curves for pollen cores from Lakes Rotomanuka, Rotokauri, and Okoroire. Sedimentation rates are based on linear interpolation between dated tephra layers. Tephra abbreviations and ages are based on Table 1 and Fig. 2.

\section{Palynology}

\section{Sampling}

Sample positions are shown in Fig. 2. At each lake a master core-A1-was designated for each site and subsequent cores for the site correlated to the master using the tephra layers as marker horizons, so palynological samples could be referenced to a single site profile (Fig. 2), and more detailed and longer palynostratigraphies could be provided. As well, this strategy allowed a flexible approach, with some replication, to sampling for palynology, tephra analysis and radiocarbon dating. Although we are concerned here primarily with events on the regional scale, there is clearly much potential in these tephrabearing, polleniferous lake sediments for examining spatial and temporal variations in pollen deposition across a single lake basin.

Age of pollen samples

By assuming a linear sedimentation rate for the deposition of a section of lake sediment 
separating two tephra layers (Fig. 3), the age of each sample was estimated from its downcore depth. Slow sedimentation rates mean that most pollen samples (each comprising c. $10 \mathrm{~mm}$ vertically of sediment) encapsulate the history of perhaps 100 years or so of pollen deposition.

\section{Slide preparation and counting}

Pollen samples were prepared following standard procedures (e.g. Faegri and Iversen, 1964). About one half of the L. Rotomanuka samples were prepared by Department of Scientific and Industrial Research (DSIR) Botany Division staff, Christchurch, and the remaining samples were prepared at Auckland University (AU). The AU samples were passed through $10 \mu \mathrm{m}$ mesh sieves to concentrate the palynomorphs (Cwynar et al., 1979). The DSIR samples were not sieved, but were instead bleached with sodium chlorate to remove residual organic material following acetolysis. Counting proceeded until a sum of at least 250 pollens from dryland taxa (including Leptospermum, excluding Pteridium) was achieved.

Tablets of exotic Lycopodium spores of known concentrations were added to each sample to facilitate the estimation of pollen concentrations (Benninghof, 1962). Pollen accumulation rates (in grains $/ \mathrm{cm}^{2} /$ yr) were estimated by multiplying pollen concentration (grains $/ \mathrm{cm}^{3}$ ) by the appropriate estimated sedimentation rate $(\mathrm{cm} / \mathrm{yr})$. Similarly, estimates of (microscopic) charcoal accumulation rates $\left(\mathrm{mm}^{2} / \mathrm{cm}^{2} /\right.$ year) were obtained for each pollen sample (following Clark, 1982) and are included in the pollen diagrams.

\section{RESULTS}

The palynostratigraphies (Fig. 4-6) have been subdivided into local pollen assemblage zones (LPAZ) and subzones according to changes in the dominant tree taxa. Because the changes that distinguish zones are usually gradual rather than distinct, the zone boundaries are difficult to define precisely. This is particularly so for the pre-Rerewhakaaitu Ash sediments that have accumulated more rapidly and contain fewer tephra layers than the overlying sediments. Nevertheless, the zonation scheme assists the comparative description of the palynostratigraphies. The LPAZ are described in the captions at the base of each diagram (Fig. 4-6).

The last glacial stage: before $\mathbf{1 4 , 5 0 0}$ years ago. (Zones Ro1, Ok1 in Fig. 4, 5).

The earliest sediments in the Rotomanuka and Okoroire cores indicate that from $c$. 18,000 years ago, around the maximum of the last glacial stage in New Zealand (Nelson et al., 1985), until just before 14,000 years ago, the Waikato lowlands remained largely unforested. Areas of open ground were common within a scrub-dominated landscape. Subalpine shrubs (e.g. Phyllocladus aspleniifolius var alpinus, Halocarpus, Coprosma spp.), grasses and herbaceous Compositae species were probably growing close to these sites at this time, together with plants from genera typically under-represented in pollen assemblages (e.g. Pseudopanax, Hoheria, Pittosporum, Hebe, Dracophyllum). In contrast, the Nothofagus and Libocedrus pollen could have travelled long distances, and these trees were not necessarily present locally. However, the high percentages (15-30\%) at Lake Rotomanuka of Nothofagus menziesii pollen, which is not widely dispersed (McKellar, 1973; Macphail and McQueen, 1983), indicate that stands of silver beech almost certainly grew near this site. Similar percentages of $N$. menziesii pollen are found in inland Taranaki in peats containing silver beech leaves (R.M. Newnham, unpublished data).

Comparable pollen assemblages, but with more Gramineae and fewer tree pollen, are reported from c. 20,000 year old peat deposits from Hamilton and Cambridge (McGlone et al., 1978), within $20 \mathrm{~km}$ of Lake Rotomanuka. These assemblages were interpreted to indicate a cool, possibly dry and windy climate (see also Gates, 1976; Thiede, 1979; Kennedy et al., 1978; Stewart and Neall, 1984; Salinger, 1984), but the presence of Leptocarpus similis and Phormium tenax possibly restricts maximum temperature depression for this period to not more than $c .4^{\circ} \mathrm{C}$ (McGlone et al., 1978). A younger sample from Rototuna peat near Hamilton, aged 18,000 years B.P. (McGlone et al., 1978), contained more tree pollen, indicating that $N$. fusca group trees were spreading at this time. 


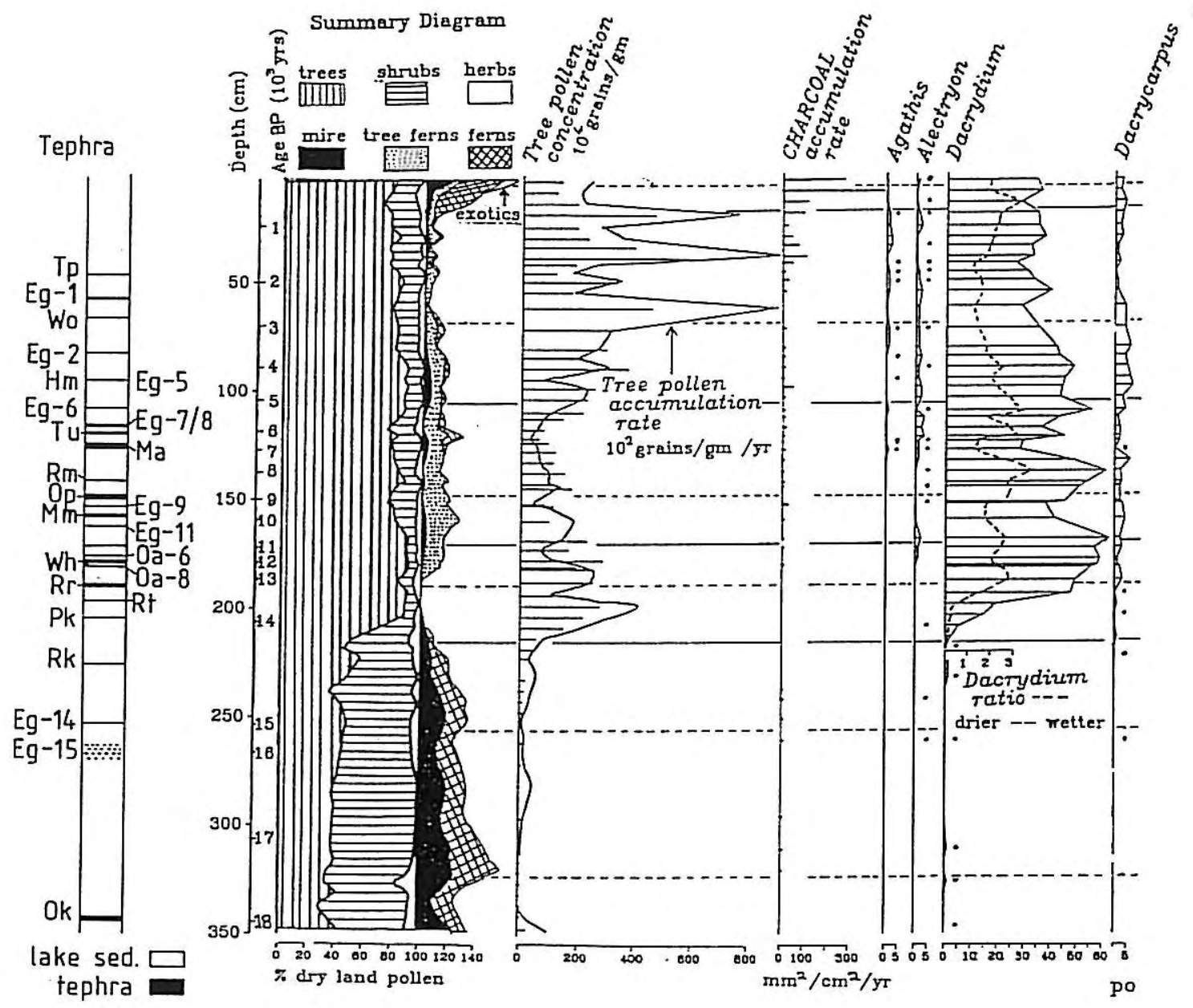

Fig. 4-Lake Rotomanuka dry land pollen percentage diagram. Local pollen assemblage zones (LPAZ) described as follows:

\begin{tabular}{|c|c|c|}
\hline ZONE & AGE & MAIN TAXA \\
\hline Ro5 & $\begin{array}{l}0.8 \text { ?-top of } \\
\text { core }\end{array}$ & Dacrydium-Pteridium-charcoal \\
\hline Ro4 & $5.2-0.8 ?$ & Dacrydium-Phyllocladus \\
\hline Ro3 & $11.0-5.2$ & Dacrydium-hardwoods-tree ferns \\
\hline Ro2 & $14.5-11.0$ & Prumnopitys taxifolia-Dacrydium \\
\hline Ro1 & $18.1-14.5$ & $\begin{array}{l}\text { Nothofagus-Halocarpus- } \\
\text { Coprosma-Leptospermum }\end{array}$ \\
\hline
\end{tabular}

SUBZONE

$\mathrm{b}$
$\mathrm{a}$
$\mathrm{b}$
$\mathrm{a}$
$\mathrm{b}$
$\mathrm{a}$
$\mathrm{b}$
$\mathrm{a}$
$\mathrm{c}$
$\mathrm{b}$
$\mathrm{a}$




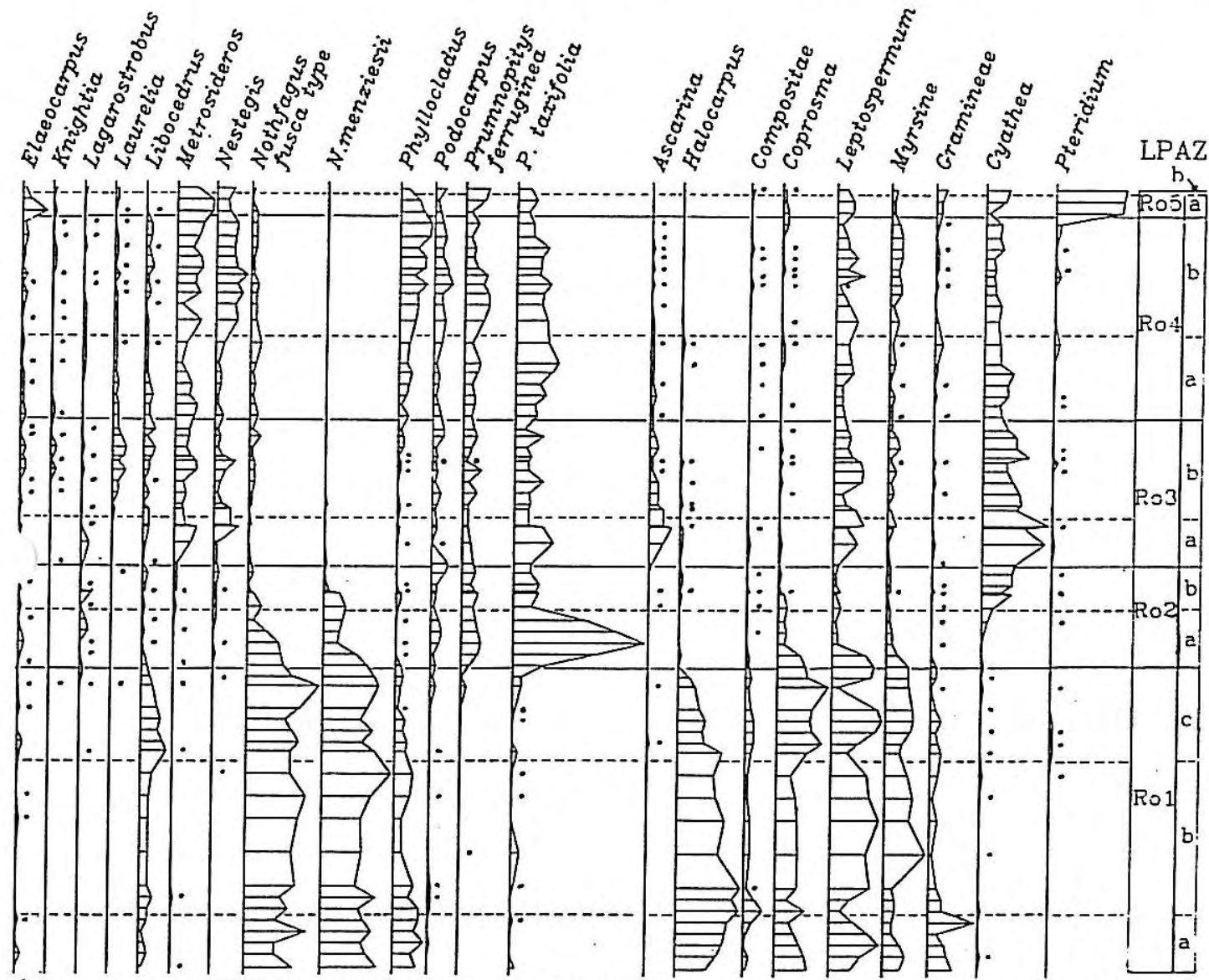

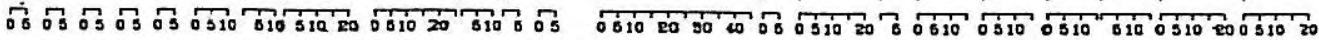

llen sum $=$ total dry land pollen

- denotes $<1 \%$

AGE

DESCRIPTION

0.1

$0.8 ?-0.1$

Exotics present

3.0-0.8?

$5.2-3.0$

8.8-5.2

$11.0-8.8$

$13.3-11.0$

14.5-13.3

Exotics absent

$15.5-14.5$

$17.5-15.5$

Phyllocladus $>5 \%$; Agathis, Nestegis, Metrosideros more common; Ascarina rare

Dacrydium ratio falls; Agathis rare; Phyllocladus low $(<5 \%)$

Ascarina falls gradually; Alectryon, Laurelia rise

Dacrydium relatively low; Ascarina,Metrosideros,Nestegis, Cyathea rise

Dacydium dominant; P.taxifolia prominent; Nothofagus rare

P.taxifolia dominant; Nothofagus fall

Halocarpus, Phyllocladus, Libocedrus low; Nothofagus, Coprosma high

Gramineae lower; Halocarpus, Phyllocladus high but falling

$18.1-17.5$

Gramineae \& Phyllocladus high 


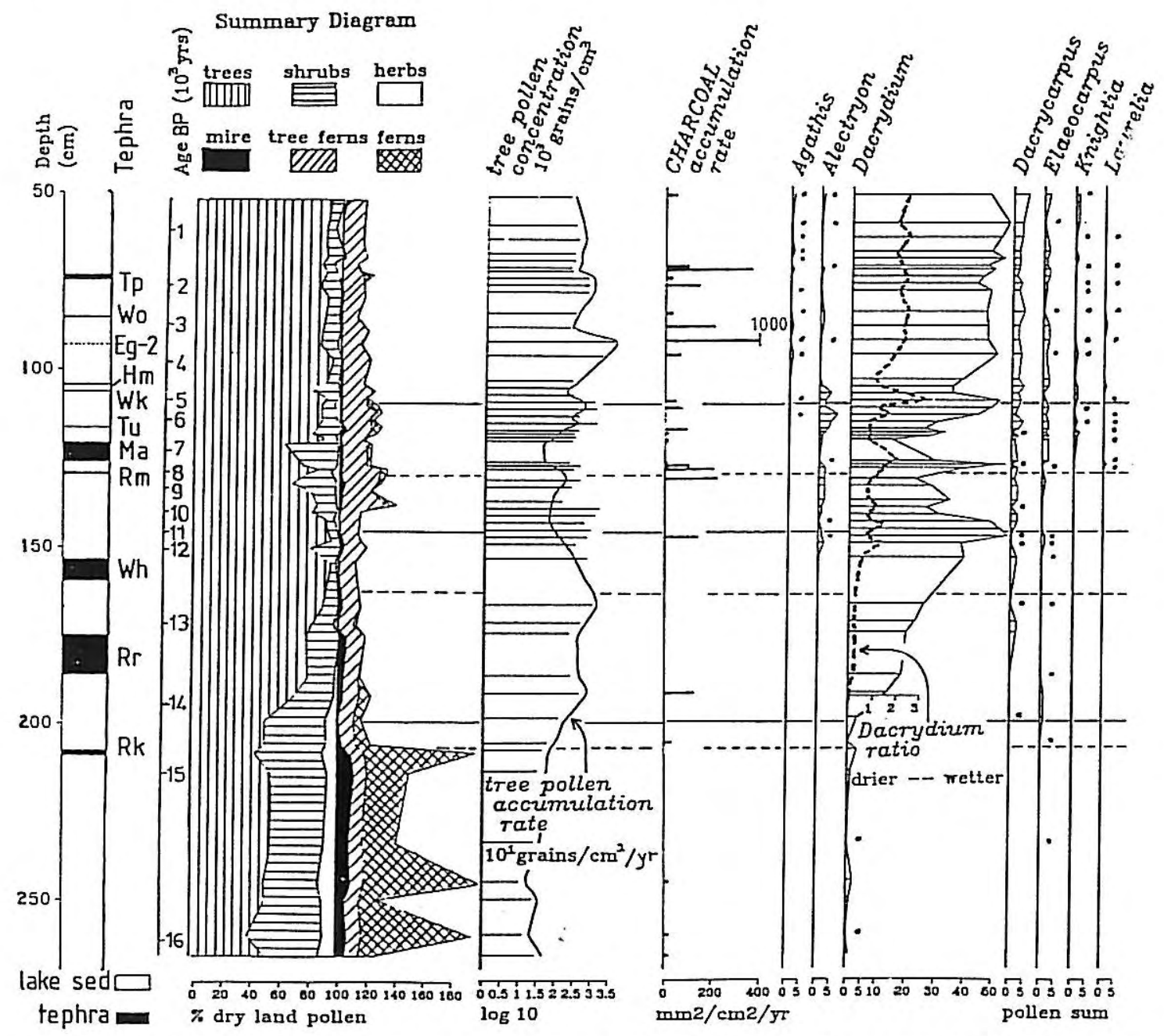

Fig. 5-Lake Okoroire dry land pollen percentage diagram. Local pollen assemblage zones (LPAZ) described as follows:

\begin{tabular}{|c|c|c|}
\hline ZONE & AGE & MAIN TAXA \\
\hline Ok4 & $\begin{array}{l}5.5 \text {-top } \\
\text { of core }\end{array}$ & Dacrydium-Prumnopitys \\
\hline Ok3 & $11.0-5.5$ & $\begin{array}{l}\text { Dacrydium-Prumnopitys } \\
\text {-hardwoods-tree ferns }\end{array}$ \\
\hline Ok2 & $14.5-11.0$ & $\begin{array}{l}\text { Prumnopitys taxifolia- } \\
\text { Dacrydium }\end{array}$ \\
\hline Ok1 & ?16.0-14.5 & $\begin{array}{l}\text { Nothofagus-Halocarpus- } \\
\text { Coprosma- }\end{array}$ \\
\hline
\end{tabular}

SUBZONE

$\mathrm{b}$
$\mathrm{a}$
$\mathrm{b}$
$\mathrm{a}$
$\mathrm{b}$
$\mathrm{a}$




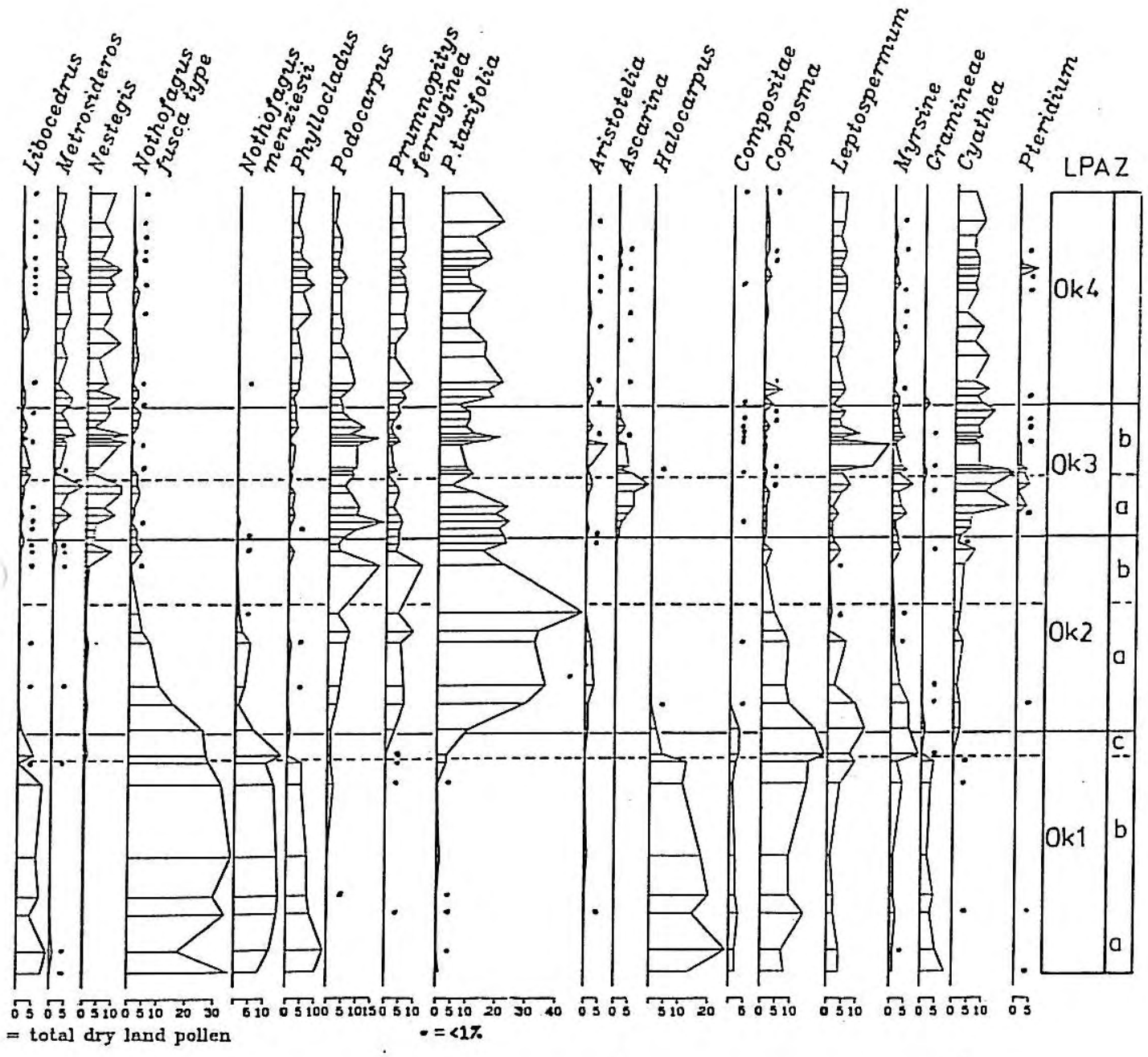

AGE

DESCRIPTION

No subzones recognised: zone characterised by increasing

Phyllocladus and Agathis (esp. after 3.0); Ascarina rare, Prumnopitys taxifolia higher

8.5-5.5 Dacrydium high; Ascarina,Metrosideros, Nestegis, Cyathea, P.taxifolia low

11.0-5.5 reverse of above,i.e. Dacrydium lower; Ascarina,etc. high

12.7-11.0 Dacydium dominant; P.taxifolia prominent; Nothofagus rare

14.5-12.7 P.taxifolia dominant; Nothofagus fall

14.7-14.5 Halocarpus, Phyllocladus, Libocedrus low; N.menziesii, Coprosma,Myrsine high

?16.0-14.7 Gramineae,Halocarpus and Phyllocladus falling 


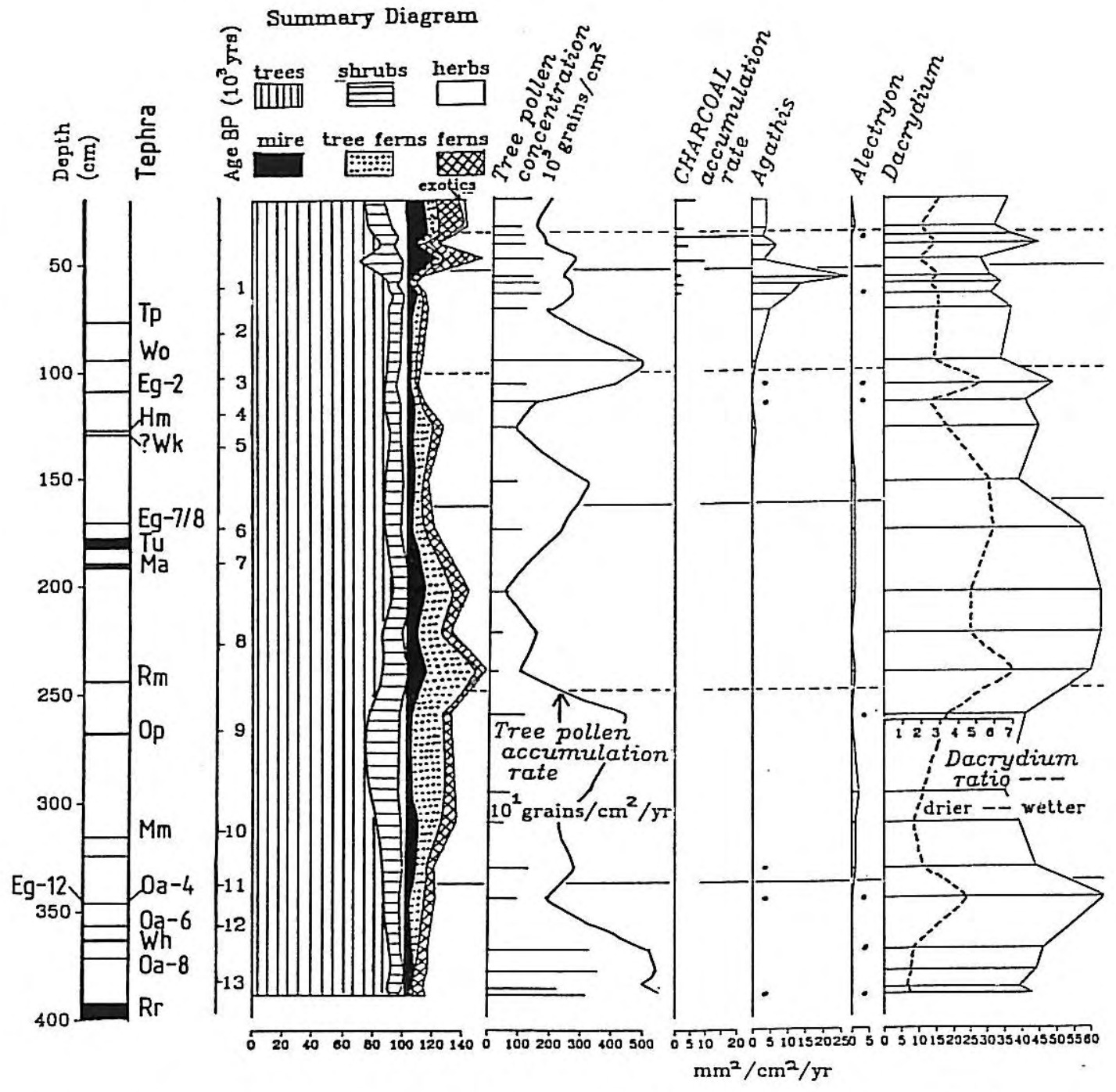

Fig. 6-Lake Rotokauri dry land pollen percentage diagram. Local pollen assemblage zones (LPAZ) described as follows:

\begin{tabular}{|c|c|c|}
\hline ZONE & AGE & MAIN TAXA \\
\hline $\mathrm{Rk4}$ & $\begin{array}{l}0.8 \text {-top } \\
\text { of core }\end{array}$ & $\begin{array}{l}\text { Dacrydium-Pteridium- } \\
\text { charcoal }\end{array}$ \\
\hline $\mathrm{Rk} 3$ & $5.7-0.8$ & Dacrydium-Phyllocladus \\
\hline $\mathrm{Rk} 2$ & $11.0-5.7$ & $\begin{array}{l}\text { Dacrydium-hardwoods- } \\
\text { tree ferns }\end{array}$ \\
\hline Rk1 & $13.3-11.0$ & Prumnopitys taxifolia-Dacrydium \\
\hline
\end{tabular}

SUBZONE

$\mathrm{b}$
$\mathrm{a}$
$\mathrm{b}$
$\mathrm{a}$
$\mathrm{b}$
$\mathrm{a}$




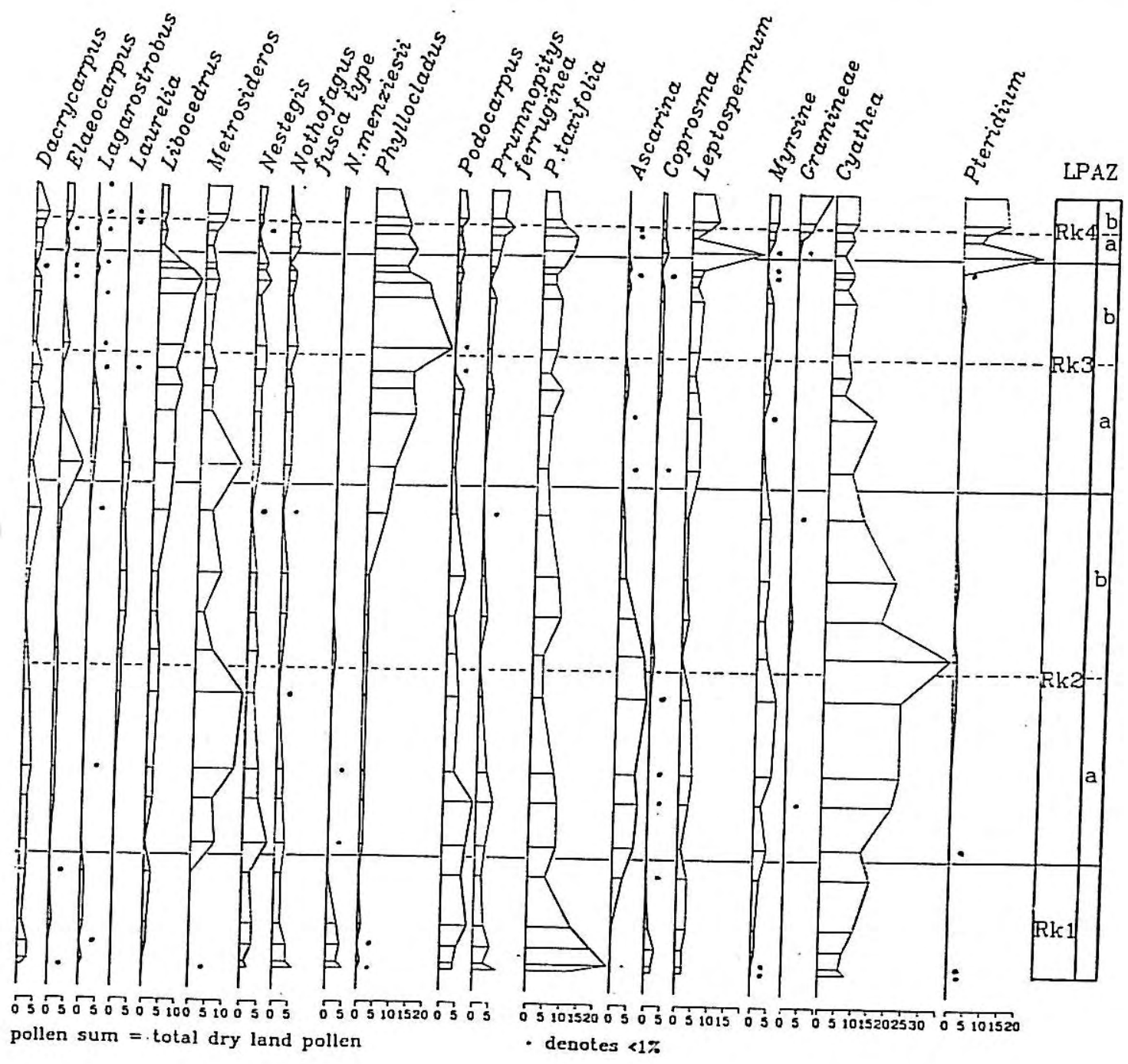

AGE

0.1

$0.8-0.1$

$3.0-0.8$

$5.7-3.0$

$8.5-5.7$

$11.0-8.5$
DESCRIPTION

Exotics present

Exotics absent

Phyllocladus common but falls; Agathis rises; Dacrydium decline continues Dacrydium ratio falls; Phyllocladus increasing

Ascarina, Metrosideros fall; Dacrydium high

Dacrydium relatively low; Ascarina,Metrosideros, Cyathea high

Dacydium rises; P.taxifolia falls 
This trend away from open grasslands and subalpine shrubs towards Nothofagus trees appears to have continued in the earliest pollen zones at Lakes Rotomanuka (Fig. 4) and Okoroire (Fig. 5) between c. 18,000-14,000 years ago. The temporal succession is to some extent paralleled in modern altitudinal plant distributions, allowing some estimations of paleotemperature changes. Phyllocladus aspleniiffolius var alpinus and Halocarpus biformis are today restricted to very high ground $(>760 \mathrm{~m})$ in the Kaimai/Mamaku Range bordering eastern Waikato (Fig. 1; B.D. Clarkson, pers. comm., 1988), but were almost certainly flourishing in the Waikato lowlands until about 16,000-15,000 years ago, after which they declined. A temperature drop of $4.2^{\circ} \mathrm{C}$ estimated from a lapse rate of $0.6^{\circ} \mathrm{C} / 100 \mathrm{~m}$, which may apply in the Kaimai Range today (Jane and Green, 1983), is less than the $6-7^{\circ} \mathrm{C}$ postulated by Willett (1950), but accords with more recent estimates for the late glacial maximum temperature depression for New Zealand (e.g. Wardle, 1963; Porter, 1975; Gates, 1976; McGlone et al., 1978; Wilson, 1978; Soons, 1979; Salinger, 1984). Similarly, the persistence in the vicinity of Lake Rotomanuka until around 13,000-14,000 years ago of $N$. menziesii, a tree that today is generally restricted to altitudes above $550 \mathrm{~m}$ in the Kaimai/Mamaku Range (B.D. Clarkson, pers. comm., 1988; cf. Clayton-Greene, 1978), may indicate that temperatures, although increasing, were still as much as $3^{\circ} \mathrm{C}$ below present levels at that time.

Lateglacial transition: 14,500-11,000 years ago (Zones Ro2, Ok2, Rk1 in Fig. 4-6)

Soon after the deposition of Rerewhakaaitu Ash (Rk), c. 14,700 years ago, substantial changes show in the pollen assemblages as the subalpine elements are progressively replaced by pollen from the tall podocarp trees, initially Prumnopitys taxifolia and then Dacrydium cupressinum. The expansion of podocarp forest is recorded simultaneously at Lakes Okoroire and Rotomanuka (the oldest sediments in the Lake Rotokauri pollen profile are less than 14,000 years in age), and appears to have been synchronous throughout the north-central North Island (McGlone, 1983a, 1985).

The early forests were dominated by $P$. taxifolia, and for about 1,000 years, one or more cohorts of these trees prospered in the western Waikato, probably on terraces left in the wake of the subsiding ancestral Waikato River system. To the east, at Lake Okoroire (Fig. 5), they persisted longer, perhaps for two generations. The late glacial abundance of $P$. taxifolia and concomitant suppression of $D$. cupressinum is consistent with a relatively cool and dry, but ameliorating, climate. Because of its ability to withstand frosts and drier conditions (Nicholls, 1983), P. taxifolia may have held a competitive advantage over D. cupressinum, which prefers moister areas (Franklin, 1968) and may be more susceptible to drought (Atkinson and Greenwood, 1972; Ogden, 1976) and to frost (Sakai et al., 1981). However, the dominance of $P$. taxifolia was almost certainly not due to climate alone; it is an early coloniser of fresh alluvial soils (Beveridge, 1983), which had recently become available as fluvial aggradation diminished, and may also have benefitted from the addition of airfall volcanic material deposited as the Rerewhakaaitu and other subsequent tephra layers (Lowe, 1988).

Temporal succession from $P$. taxifolia-dominant forests to $D$. cupressinum-dominant forest is documented at a number of New Zealand palynological sites covering the late glacial to Holocene transition period. Although reafforestation was completed at different times in New Zealand - around 10,000 years ago in Southland (McGlone and Bathgate, 1983) and north Westland (Moar,1971); around 12,000 to 13,000 years ago in Taranaki (McGlone and Neall pers. comm., 1988) and Manawatu (Lees, 1986); around 14,000 years ago in the central North Island (McGlone and Topping, 1977) and Waikato lowlands (this study) - palynological evidence from all these regions shows a local temporal sequence from shrubland-grassland through $P$. taxifolia-dominated forest to $D$. cupressinum-dominant forest. The general trend, of reafforestation proceeding later at more southern sites, is consistent with other evidence for warming during this period (e.g. Suggate, 1965; Hendy and Wilson, 1978; Chinn, 1983). We therefore prefer the explanation that climate, drier and cooler initially (at $c .14,500$ years ago), but becoming increasingly wetter and warmer, was the dominant factor favouring the expansion of $P$. taxifolia ahead of $D$. cupressinum. We suggest, moreover, that at some sites (e.g. in the Waikato lowlands), the availability of fresh alluvial or tephra-derived soils accentuated the early dominance of $P$ taxifolia. 
This may also explain why $P$. taxifolia persisted longer in the eastern Waikato than in the west; Lake Okoroire is closer to most of the Late Quaternary eruptive centres and in particular to the Okataina source than the Hamilton Basin lakes, and accordingly its sediments contain much thicker tephra (see Fig. 2, 4-6).

The rapidity of forest expansion, and the presence of Prumnopitys, Dacrydium, and Podocarpus pollen in low frequencies in the late glacial sediments of these lakes, corroborate McGlone's (1983a, 1985) suggestion that these podocarps were probably present in low numbers in this region before reafforestation, occupying sites that permitted survival but not expansion. In addition to a cooler and windier climate, the extensive high-energy fluvial aggradation of the Hinuera Formation in the Waikato lowlands (Fig. 1) during the late glacial, between c. 19,000 and 16,000 years ago (Hume et al., 1975; McGlone et al., 1978; Green and Lowe, 1985) must have presented a formidable barrier to the spread of forests.

There is now strong evidence for major environmental changes developing throughout New Zealand during the period from $c$. 14,500 to 11,000 years ago. As forests of lowland, warm-temperate character were replacing subalpine, cool-temperate vegetation in the Waikato lowlands and central North Island, glaciers were retreating from their maximum extension in western South Island (Suggate, 1965; Suggate and Moar, 1970; Burrows, 1979; Chinn, 1983); the accumulation of terrigenous wind-borne quartz off the coast of eastern North Island, which had been rapid, decreased abruptly, presumably as westerly winds subsided and as aggradational surfaces on land became forested (Stewart and Neall, 1984); tephric-sand dunes stabilised in northern Taranaki (Neall, 1975); deposition of loess in southern North Island and South Island virtually ceased (McCraw, 1975; Milne and Smalley, 1979); erosion of interfluves ceased (Leamy et al., 1973); and rates of soil formation increased in central North Island (Vucetich and Pullar, 1963, 1969; Birrell and Pullar, 1973; Birrell et al., 1977; Lowe, 1986).

We are able directly to compare many of these events and so establish their synchroneity because of the widespread deposition of Rerewhakaaitu Ash throughout central and northcentral North Island. Furthermore, its dispersal at a time when much of this region was at the threshold of reafforestation increases its value as a stratigraphic marker.

Early postglacial: 11,000-5,500 yrs B.P. (Zones Ro3, Ok3, Rk2 in Fig. 4-6)

After c. 11,000 years ago, all three sites record increases of tree ferns and of several angiosperm trees (especially Nestegis, Metrosideros, Alectryon, Laurelia, Elaeocarpus). Evidently the early podocarp-dominated forests were opening out, so providing space and light for other canopy and subcanopy species to exploit. Previous palynological evidence from throughout New Zealand indicates the period from 10,000 to 8,000 years ago to be the time of maximum postglacial forest expansion (Moar, 1971; Lintott and Burrows, 1973; McGlone and Topping, 1977; Mildenhall, 1979; Mildenhall and Brown, 1987) and Pittock and Salinger (1983) refer to this period as a "climatic optimum". The three sites investigated here all record maximum levels of Dacrydium and Ascarina pollen, suggesting a wetter and perhaps warmer climate than during any other period covered here. These conclusions agree with the findings of Hendy and Wilson (1968), Green (1979), and Green and Lowe (1985).

Marked fluctuations in the Dacrydium pollen curve during late- and early post-glacial times appear to be synchronous at the three lake sites. There are peaks in Dacrydium pollen percentages from Lakes Rotomanuka and Okoroire at around 11,000, 8,000 (between the deposition of Rotoma Ash and Mamaku Ash), and 5,500 years ago, and both sites record a smaller peak at around 6,300 years ago (Fig. 4, 5). Samples from the Lake Rotokauri cores, although more widely spaced, nevertheless also show peaks at $c .11,000$ and 8,000 years ago (Fig. 6). The analysis of L. Rotokauri core A2 (R. M. Newnham, unpublished data) shows Dacrydium peaks at c. 11,000, 8,000, and 6,300 years ago. The Dacrydium peaks are terminated abruptly, and followed by gradual recovery during which a range of ecologically diverse species flourish. Some of these (e.g. Cyathea, Leptospermum, Pteridium, Aristotelia) are plants that typically respond quickly to disturbance within forests, whereas others (e.g. Prumnopitys taxifolia, Metrosideros, Nestegis) are competitors for canopy 
space. The cyclic nature of these Dacrydium peaks and their sudden terminations suggest they are not due to long term climatic change. We suggest instead an ecological control, as follows. $D$. cupressinum trees, which are slow growing and long-lived (generally about 600 years, and some live 1200 years: Norton et al., 1988; C.H. Lusk, unpublished data), were well suited to the warm and wet climates of this time. At all three sites the evidence consistently shows that at around 12,500 years ago, $P$. taxifolia was replaced by $D$. cupressinum as the most important canopy species in these young forests. By 11,000 years ago, tall, mature $D$. cupressinum trees must have dominated the canopy and emergent layers. Older emergents were particularly susceptible to windthrow during low-frequency, high-intensity storms. These storms would therefore have created new opportunities for canopy competitors and smaller seral species (Norton et al., 1988), as well as increasing the susceptibility of the whole forest to fire in drier summers. There is strong evidence for increased burning at Lake Okoroire (Fig. 5), where the Dacrydium peaks (especially at c. 8,000 years ago) correspond with charcoal peaks, and subsequent assemblages record increases in taxa which typically feature in post-fire succession, notably Pteridium, Leptospermum, and Aristotelia. Dacrydium pollen remains important, but diminished, in the subsequent assemblages; hence it took perhaps 2,000-3,000 years for $D$. cupressinum to achieve its former dominance.

These regular c. 3,000 year cycles of Dacrydium dominance are most evident in lateglacial and early postglacial assemblages, but similar and possibly analagous fluctuations recur throughout the Dacrydium pollen curves at these lake sites and may be detectable at other pollen sites with adequate age control. Recent studies in New Zealand plant demography (e.g. Veblen and Stewart, 1982; Ogden, 1985) suggest that periodic, catastrophic disturbances play an important role in the regeneration and population dynamics of modern forests.

Ascarina pollen curves are remarkably similar at all three sites. Rare or absent before the initial Dacrydium peak at $c$. 11,000 years ago, Ascarina pollen percentages rise rapidly afterwards, suggesting that it was also responding to forest disturbance. The Ascarina pollen curves peak between c. 10,000-9,000 years ago, then taper off. This pattern conforms with that described by McGlone and Moar (1977) except that their postulated recovery between 3,400 and 1,800 years ago is not apparent at these sites. Apart from its paleoclimatic significance, there is clearly much potential for the use of Ascarina as a biostratigraphic index in late- and post-glacial terrestrial sediments (Fig. 7).

As well as Ascarina, Cyathea tree ferns were common in the subcanopy of these early postglacial forests. Nestegis, Alectryon, Elaeocarpus, and Laurelia formed the forest canopy, presumably with Beilschmiedia tawa which is grossly under-represented in pollen spectra (Macphail, 1980). D. cupressinum, probably supporting Metrosideros lianes, was the most common emergent. $M$. robusta is likely to have been more common than its pollen percentages would suggest. $M$. robusta pollen can normally be distinguished from other Metrosideros species, except $M$. excelsa (McIntyre, 1963), but this distinction cannot always be confidently made with fossil specimens. Thus the $M$. robusta percentages are minimum estimates, and some grains, conservatively recorded as Metrosideros, are possibly $M$. robusta. Prumnopitys spp. and Podocarpus spp. were also common canopy and emergent trees, although they had been more abundant before 11,000 years ago and increased after 5,500 years ago when, except at L. Okoroire, Dacrydium steadily declined.

Late postglacial: 5,500 years ago to recent (Zones Ro4, Ok4, Rk3 in Fig. 4-6)

Shifts in the relative prominence of Prumnopitys and Podocarpus species compared with Dacrydium, as reflected in the Dacrydium ratio, have been used previously (Harris, 1963; McGlone and Topping, 1977; McGlone et al., 1984), along with other evidence, to indicate drier climates during the late Holocene, after about 5,000 years ago (see also Green, 1979; Green and Lowe, 1985). Lakes Rotokauri and Rotomanuka provide ample evidence for drier conditions after about 5,500 years ago: the Dacrydium ratio shows the increasing importance of the more drought-tolerant tree podocarps; Ascarina and Cyathea, which today favour moister areas, decline; Phyllocladus and Agathis, two associated species favouring drier sites, become increasingly important; and increasing rates of charcoal accumulation indicate more frequent fires around the lakes. 
At Lake Okoroire (Fig. 5), the decline of Ascarina and Cyathea and the increasing percentages of Prumnopitys, Podocarpus, Phyllocladus, and Agathis pollen plus greater charcoal accumulation suggest that these characteristics of increasing dryness were extensive throughout the region. However, the high Dacrydium ratio and high Dacrydium pollen percentages appear to contradict this trend. $D$. cupressinum can persist in regionally drier areas today by occupying the moister low-lying sites (Franklin, 1968), and commonly grows on boggy ground. As all the evidence from these three sites - with this one exception-points unequivocally to drier climates, the falling water levels and the availability of boggy ground around Lake Okoroire after c. 6,000 years ago may have allowed $D$. cupressinum trees, although declining regionally, to thrive locally, thus contradicting the regional decline in Dacrydium pollen at the other Waikato sites at Lakes Rotokauri and Rotomanuka (see also Harris, 1963; McGlone et al., 1984). Falling lake levels may also explain the late postglacial increase in concentration and rate of accumulation of tree pollens observed at all three sites (Fig. 4-6), because they enabled source plants to grow closer to the point of pollen deposition on the lake floor.

At about the same time Dacrydium was spreading on to the previously submerged peaty substrates surrounding Lake Okoroire, $A$. australis was also spreading around Lake Rotokauri, possibly invading previously swampy marginal areas that were drying out as the lake level dropped. Agathis is often poorly represented in New Zealand pollen assemblages (Macphail and McQueen, 1983), unless large $A$. australis stands are nearby (R.M. Newnham, unpublished data), and the $25 \%$ Agathis pollen in the c. 1,000 year old Lake Rotokauri sample (Fig. 6) is among the highest yet recorded. It seems likely, therefore, that the largest of the Agathis logs, reported by earlier workers and still to be seen around Lake Rotokauri, date from around this time. The three records for Agathis presented here are consistent with other published evidence from northern localities (McGlone et al., 1984; Kershaw and Strickland, 1988) in showing increasing Agathis after c. 6,000 years ago, but there is a second, more substantial expansion at around c. 3,000 years ago in the Waikato lowlands.

\section{The Taupo eruption}

Sediments sampled immediately above Taupo Pumice at each of the lake sites show evidence, in the form of shortlived peaks of Pteridium and charcoal accumulation, of forest fires (Fig. 4-6). Vegetation disturbance following tephra fall, in particular Kaharoa Ash and Taupo Pumice, has been discussed by McGlone (1980), who suggested that fires were more likely to follow these eruptions because they occurred during periods of drier climate. Apart from the immediately post-Taupo Pumice sediments there is little direct evidence in the lake sediments examined here of vegetation disturbance after the numerous preTaupo tephra deposits, even though several of these (e.g. Rotorua Ash, Waiohau Ash, and Mamaku Ash) are much thicker deposits and represent major eruptions (Lowe, 1988). Tephra-related fires must have been extensive, because they are recorded at some distance (100-120 km) upwind of the postulated centre of the Taupo eruption (Wilson, 1985). We therefore agree with McGlone's (1980) view that conditions during and immediately following the Taupo Pumice eruption must have been exceptional to allow such damage. Since the land was uninhabited, perhaps this indicates an exceptionally dry climate.

\section{Deforestation and Human Settlement}

After the Taupo Pumice eruption 1,800 years ago and before the arrival of European settlers, the lowland Waikato forests suffered more dramatic changes than recorded over the previous 13,000 years. The sharp rise and sustained peak of the Pteridium curve, together with increases in other indicators of disturbance; the considerable increase in charcoal accumulation rates; and the decline of many forest tree taxa follow precisely the pattern that McGlone $(1980,1983 \mathrm{c}$ ) attributed to the burning of forests by early Polynesian settlers. There is no evidence in these sediments for climate-related erosional events in post-Taupo time as postulated by Grant (1985) and by McFadgen (1985). Instead, the scale of disturbance, and the clear distinction between the pre-disturbance and post-disturbance character of these post-Taupo sediments undoubtedly point to human agency. 
Anthropogenic forest clearance at $\mathrm{L}$. Rotokauri began around 800 radiocarbon years ago, based on the radiocarbon age of $810 \pm 90$ years B.P. (Wk-1245; Fig. 2), obtained from lake sediment containing the earliest significant evidence of post-Taupo Pumice disturbance (the Pteridium content of the $2 \mathrm{~cm}$-thick dated sample increased from $2 \%$ at the base to $40 \%$ at the top of the slice, and the Agathis content fell from $25 \%$ to $3 \%$ ). Based on the corrections and calibration procedures of Stuiver and Pearson (1986), Wk-1245 corresponds to a calibrated age of A.D. 1259 (with 1 std. dev. errors, age is between A.D. 1175-1280, i.e. 775-670 calibrated years B.P.). The date is similar to others from nearby Lake Hakanoa (Fig. 1; Hogg et al., 1987) and corroborates McGlone's (1983c) estimates for the timing of widespread Polynesian deforestation elsewhere in New Zealand.

A distinct sedimentary transition (marked by a dashed line in Fig. 2) from firm, compact lake sediment below to wetter, uncompacted lake sediment above, coincides with the initiation of the Pteridium-charcoal phase $c$. 800 years ago. The sediments below this point show no significant palynological or sedimentary evidence of catchment disturbance, apart from that immediately following the deposition of Taupo Pumice noted above. An age of $1220 \pm 90$ years B.P. (Wk-1244; Fig. 2) was obtained from a $2 \mathrm{~cm}$-thick slice of these sediments $5 \mathrm{~cm}$ below the Pteridium-charcoal transition point (i.e. below Wk-1245). The rate of sedimentation since 1800 years ago increases from $c .0 .23 \mathrm{~mm} / \mathrm{yr}$ before to $c .0 .56$ $\mathrm{mm} / \mathrm{yr}$ after the deforestation around $\mathrm{L}$. Rotokauri.

At Lake Rotomanuka, a parallel pattern of pre- and post-forest disturbance is evident (Fig. 4). Based on estimated sedimentation rates (radiocarbon dates have not yet been obtained for this part of the record at L. Rotomanuka), we consider that deforestation began here at around the same time as at L. Rotokauri. We found no comparable evidence for deforestation in post-Taupo Pumice sediments at Lake Okoroire (Fig. 5), probably because of difficulty in adequately sampling the topmost sediments, which were very sloppy in this lake.

\begin{tabular}{|c|c|c|c|c|}
\hline Yrs BP & RPAZ & Key Pollen Taxa & Regional Vegetation & Climate \\
\hline 0.15 & $\begin{array}{l}5 b \\
5 a\end{array}$ & $\begin{array}{l}\text { Pteridium-exotics } \\
\text { Pteridium-charcoal }\end{array}$ & $\begin{array}{l}\text { Cleared ground \& } \\
\text { podocarp-hardwood } \\
\text { forest }\end{array}$ & $?$ \\
\hline $\begin{array}{l}1 \\
2 \\
3\end{array}$ & $4 b$ & $\begin{array}{l}\text { Agathis } \\
\text { Phyllocladus } \\
\text { Dacrydium ratio (-) } \\
\text { Phyllocladus }\end{array}$ & $\begin{array}{l}\text { Podocarp hardwood } \\
\text { \& kauri forest }\end{array}$ & $\begin{array}{l}\text { Cooler and } \\
\text { drier; } \\
\text { droughts, } \\
\text { frosts } \\
\end{array}$ \\
\hline $\begin{array}{l}9 \\
10 \\
11 \\
\end{array}$ & $3 b$ & $\begin{array}{l}\text { Tree ferns decline } \\
\text { Ascarina decline } \\
\\
\text { Dacrydium ratio }(+) \\
\text { Metrosideros } \\
\text { Ascarina } \\
\end{array}$ & $\begin{array}{l}\text { Extensive } \\
\text { Podocarp-hardwood } \\
\text { Forest }\end{array}$ & $\begin{array}{l}\text { Warm \& } \\
\text { moist } \\
\text { Warmest \& } \\
\text { wettest }\end{array}$ \\
\hline $\begin{array}{l}12 \\
13\end{array}$ & $2 \mathrm{a}$ & $\begin{array}{l}\text { Nestegis, Cyathea } \\
\text { Dacrydium } \\
\text { Prumnopitys }\end{array}$ & $\begin{array}{l}\text { Early podocarp } \\
\text { forest }\end{array}$ & $\begin{array}{l}\text { Warmer \& } \\
\text { wetter }\end{array}$ \\
\hline $\begin{array}{l}16 \\
17\end{array}$ & $\begin{array}{l}1 \mathrm{a} \\
1 \mathrm{~b}\end{array}$ & $\begin{array}{l}\text { Nothofagus, Libocedrus } \\
\text { Halocarpus, Coprosma } \\
\text { Phyllocladus }\end{array}$ & $\begin{array}{l}\text { Nothofagus scrub } \\
\& \text { grasslands }\end{array}$ & ?Moistening \\
\hline 18 & $1 \mathrm{a}$ & Gramineae, Phyllocladus & & Cool \& dry \\
\hline
\end{tabular}

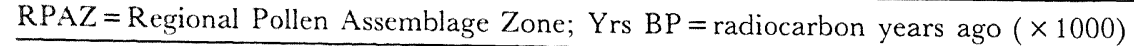


The earliest European pollen (chiefly Pinus, Cupressaceae, Plantago lanceolata) at Lake Rotokauri is recorded, in low concentrations (c. $5 \%$ ), about $5 \mathrm{~cm}$ above the deforestation transition dated at $810 \pm 90$ years B.P. (Wk-1245) and about $35 \mathrm{~cm}$ below the surface of the lake sediments. A $2 \mathrm{~cm}$-thick sample containing these first adventives returned an age of $800 \pm 80$ years B.P. (Wk-1246; Fig. 2). Clearly these uppermost sediments record a major disturbance in the catchment, or the sediment has been mixed by some other mechanism (e.g. bioturbation or wind-induced wave mixing - see Schicker, 1987; Lowe, 1988), because the earliest European settlers did not arrive until about A.D. 1840.

These results indicate that lake sediments with minor percentages of European pollen may not always be of European age. Furthermore, if (European) pollen can be dislocated downwards within lake sediments after deforestation of the catchment, the same may be true at other wetland sites indicating pre-European forest disturbance. It may therefore be unwise, in the absence of independent supporting evidence, to attribute the relatively minor Pteridium-charcoal levels in sediments underlying a precipitous Pteridium-charcoal rise to coeval Polynesian burning ( $c f$. Chester, 1986; Sutton, 1987).

\section{SUMMARY AND CONCLUSIONS}

The vegetational and climatic history of the Waikato lowlands region during the last c. 18,000 years is inferred from the palynology of sediment cores from three lowland lake sites (Lakes Rotomanuka, Rotokauri and Okoroire). The cores were dated and correlated using radiocarbon methods and multiple tephra layers interbedded with the sediments. Our main findings are summarised in Table 2 and Figure 7.

From $c .18,000$ to just before 14,000 years ago, the Waikato lowlands remained largely unforested. The pollen assemblages record successive peaks of herb and shrub taxa: Gramineae, Phyllocladus, Halocarpus, Coprosma. Tree pollens, mostly Nothofagus and Libocedrus, increase through this zone, probably because harsh climates - windy, relatively dry and cool (c. $4^{\circ} \mathrm{C}$ below present temperatures) - were gradually abating. Tall podocarp trees were rare but not absent from the region.

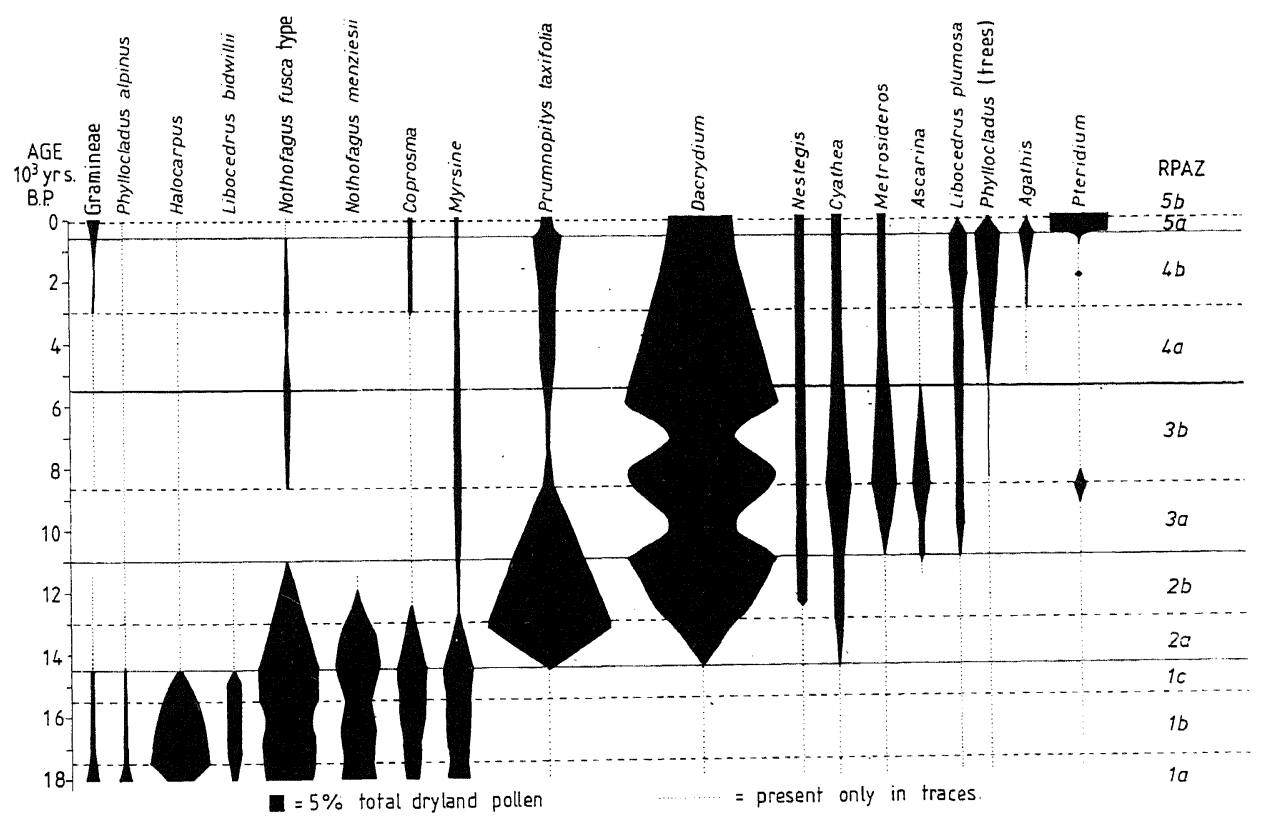

Fig. 7-Summary of Waikato regional palynostratigraphy since $c$. 18,000 years ago, based on pollen analyses of Lakes Rotomanuka, Okoroire and Rotokauri. 
Reafforestation proceeded rapidly, beginning about 14,500 years ago, soon after the deposition of Rerewhakaaitu Ash. The earliest forests were dominated by Prumnopitys taxifolia and the persistence of $N$. menziesii around 13,000-14,000 years ago suggests that temperatures may have been as much as $3^{\circ} \mathrm{C}$ colder than present. After that time $N$. menziesii disappeared from the Waikato lowlands and the predominance of Dacrydium pollen, which is maintained in all the overlying assemblages, reflects a trend towards moister and warmer conditions.

Cycles of Dacrydium dominance between 11,000 and 5,500 years ago are evidently synchronous at the three sites, and are interpreted as evidence for regionally extensive storms that destroyed emergent Dacrydium cupressinum trees by windthrow, allowing competitors for canopy space to flourish. These $D$. cupressinum perturbations indicate that palynology of postglacial pollen records can provide past analogues to modern disturbance events. The podocarp forests of New Zealand, with several long-lived, wind-pollinated canopy and emergent species, appear to be well suited to the reconciliation of modern ecological observation with the fossil record.

Beginning around 11,000 years ago, the dispersal of angiosperm trees (especially Metrosideros, Nestegis, and Ascarina) and tree ferns within Dacrydium-dominated assemblages is consistent with evidence from elsewhere in New Zealand for an early postglacial period of maximum warmth and wetness. However by $c .8,500$ years ago, Ascarina was already declining, perhaps because of increasing droughtiness or increasing frostiness, or both.

A continuation of this drying trend is evident after c. 5,500 years ago when Ascarina was rare, Phyllocladus and Agathis increased, more microscopic charcoal is recorded, and Dacrydium declined relative to the other tall podocarp trees. Increases in tree pollen concentrations and tree pollen accumulation rates may be due to falling lake levels. At all three sites investigated, Agathis pollen is most prominent after c. 3,000 years ago, reaching maximum levels around one thousand years ago.

Many tree taxa (most notably Agathis at Lake Rotokauri) were adversely affected by Polynesian burning of forests. The earliest firings are dated (Wk-1245) at $810 \pm 90$ radiocarbon years B.P. (between A.D. 1175-1280).

\section{ACKNOWLEDGEMENTS}

Matt McGlone sampled and prepared half the samples from the L. Rotomanuka cores and has continued to assist and encourage the palynological investigations. We are additionally grateful to him, and also to John Ogden, Chris Lusk, and Peter de Lange for providing comments on the manuscript. We thank Alan Hogg for his expert assistance with radiocarbon dates, Laurance Gaylor (L. Okoroire), and Gillian Turner (L. Rotokauri) for assisting with coring and sampling. Frank Bailey and Doreen Whitehead drafted Fig. 1-3; Louise Cotterall drafted Fig. 7. One of us (RMN) has been supported for the duration of this project by a New Zealand University Grants Committee (NZUGC) Scholarship and has enjoyed the patient supervision of Jack Grant-Mackie and John Braggins. The NZUGC has also assisted with funds for radiocarbon dates.

Finally, this work is only one of many New Zealand Quaternary palynological investigations to have benefitted, either directly or indirectly, from the inspiration of Neville Moar.

\section{REFERENCES}

Atkinson, I. A. E., and Greenwood, R. M., 1972. Effects of the 1969-70 drought on two remnants of indigenous lowland forest in the Manawatu district. Proceedings of the N.Z. Ecological Society 19: $34-45$.

Bellwood, P., 1978. Archaeological research at Lake Mangakaware, Waikato, 1968-1970. Otago University Studies in Prehistoric Anthropology 12.

Benninghof, W. S., 1962. Calculation of pollen and spore density in sediments by addition of exotic pollen in known quantities. Pollen et Spores 4: 332-333. 
Beveridge, A. S., 1983. Regeneration of podocarp forests and maintenance of productivity. In K. Thompson, A.P.W Hodder, and A.S. Edmonds (Eds): Lowland forests of New Zealand, pp 93-112. University of Waikato, Hamilton.

Birrell, K. S., and Pullar, W. A., 1973. Weathering of paleosols in Holocene and late Pleistocene tephras in central North Island, New Zealand. N.Z. Journal of Geology and Geophysics 16: 687-702.

Birrell, K. S., Pullar, W. A., and Searle, P. L., 1977. Weathering of Rotoehu Ash in the Bay of Plenty district. N.Z. Journal of Science 20: 303-310.

Burrows, C. J., 1979. A chronology for cool-climate episodes in the Southern Hemisphere, 12,000-1,000 B.P.. Palaeogeography, Palaeoclimatology, Palaeoecology 27: 287-347.

Chester, P., 1986. Forest clearance in the Bay of Islands. Unpublished M.A. thesis, University of Auckland.

Chinn, T. J. H., 1983. New Zealand glacial record, 10 to 15,000 B.P. In J. M. A. Chappell and A. Grindrod (Eds): Proceedings of the first CLIMANZ Conference, Howman's Gap, Victoria, Australia, Feb 8-13, 1981, pp 71-72. Australian Academy of Science, Canberra.

Clark, R., 1982. Point count estimation of charcoal in pollen preparations and thin sections. Pollen et spores 24: 523-535.

Clayton-Greene, K. A., 1976. The vegetation of Mt Karioi and forested areas in the Waikato, North Island, New Zealand. Unpublished M.Sc. thesis, University of Waikato.

- 1978. Aspects of the distribution of certain indigenous woody species in the Waikato District, New Zealand. Journal of the Royal Society of N.Z. 8: 283-291.

Cockayne, L., 1910. New Zealand Plants and their story. Engelmann, Leipzig.

Cranwell, L. M., 1939. Native vegetation. In: Soils and agriculture of part of Waipa County. D.S.I.R. Bulletin 76: 23-30.

__ 1953. New Zealand pollen studies, the Monocotyledons. Bulletin of the Auckland Institute and Museum 3.

Cranwell, L. M. and von Post, L., 1936. Post-Pleistocene pollen diagrams from the Southern Hemisphere 1: New Zealand. Geografiska Annaler 3-4: 308-347.

Cwynar, L. C., Burden, E., and McAndrews, J. H., 1979. An inexpensive sieving method for concentrating pollen and spores from fine-grained sediments. Canadian Journal of Earth Sciences 16: $1115-1120$.

de Lange, P. J., 1986. Two interesting gully systems near Koromatua. Rotorua Botanical Society Newsletter 8: 29-38.

- 1989. Koromatua Bush, Pirongia Highway. Auckland Botanical Society Journal 44: 12-22.

de Lisle, J. F., 1967. The climate of the Waikato Basin. Earth Science Journal 1: 2-16.

Dodson, J. R., Enright, N. J. and McLean, R. F., 1988. A late Quaternary vegetation history for far northern New Zealand. Journal of Biogeography 15: 647-656.

Edmonds, A. S., and Henshaw, D., 1984. The Waipa County Landscape. 2. Vegetation and Wildlife. Queen Elizabeth II National Trust, Wellington.

Enright, N. J., McLean, R. F. and Dodson, J. R., 1988. Late Holocene development of two wetlands in the Te Paki region, far northern New Zealand. Journal of the Royal Society of N.Z. 18: 369-382.

Faegri, K., and Iversen, J., 1964. Textbook of pollen analysis. Munksgaard, Copenhagen.

Franklin, D. A., 1968. Biological Flora of New Zealand 3. Dacrydium cupressinum Lamb (Podocarpaceae) Rimu. N.Z. Journal of Botany 6: 493-513.

Froggatt, P. C., and Lowe, D. J., in press. A review of late Quaternary silicic tephra formations from New Zealand: their stratigraphy, nomenclature, distribution, volume, and age. N.Z. Journal of Geology and Geophysics.

Gates, W. L., 1976. Modelling the ice-age climate. Science 191: 1138-1144.

Grant, P. J., 1985. Major periods of erosion and alluvial sedimentation in New Zealand during the late Holocene. Journal of the Royal Society of N.Z. 15: 67-121.

Green, J. D., 1979. Palaeolimnological studies on Lake Maratoto, North Island, New Zealand. In S. Horie (Ed): Palaeolimnology of Lake Biwa and the Japanese Pleistocene 7: 416-438. 
Green, J. D., and Lowe, D. J., 1985. Stratigraphy and development of c. 17,000 year old Lake Maratoto, North Island, New Zealand, with some inferences about postglacial climatic change. N.Z. Journal of Geology and Geophysics 28: 675-699.

Gudex, M. C., 1963. The native flora of Maungatautari and the Kaimai Range, and the distribution of native plants in the Waikato. Transactions of the Royal Society of N.Z., Botany 2: 173-184.

Harris, W. F., 1963. Paleo-ecological evidence from pollen and spores. Proceedings of the N.Z. Ecological Society 10: 38-44.

Hendy, C. H., and Wilson, A. T., 1968. Palaeoclimatic data from speleothems. Nature 219: 48-51.

Hogg, A. G., Lowe, D. J., and Hendy, C. H., 1987. University of Waikato radiocarbon dates 1. Radiocarbon 29: 263-301.

Hume, T. M., Sherwood, A. M., and Nelson, C. S., 1975. Alluvial sedimentology of the Upper Pleistocene Hinuera Formation, Hamilton Basin, New Zealand. Journal of the Royal Society of N.Z. 5: 421-462.

Jacobson, G. L. Jr., and Bradshaw, R. H. W., 1981. The selection of sites for paleovegetational studies. Quaternary Research 16: 80-97.

Jane, G. T., and Green, T. G. A., 1983. Ecological aspects of climatic patterns within the Kaimai Ranges, North Island, New Zealand. N.Z. Journal of Ecology 7: 183-197.

Janssen, C. R., 1973. Local and regional pollen deposition. In H.J.B. Birks and R.C. West (Ed.) Quaternary Plant Ecology, pp 31-42. Blackwell, Oxford.

Kellett, R. L., 1985. Paleosecular variation of the geomagnetic field recorded in recent lake sediments from the Hamilton Basin. Unpublished B.Sc. (Hons) thesis, Victoria University of Wellington.

Kennedy, N. M., Pullar, W. A., and Pain, C. F., 1978. Late Quaternary land surfaces and geomorphic changes in Rotorua Basin, North Island, New Zealand. N.Z. Journal of Science 21: 249-264.

Kershaw, A. P., and Strickland, K. M., 1988. A Holocene pollen diagram from Northland, New Zealand. N.Z. Journal of Botany 26: 145-152.

Kirk, T., 1871. Notes on the Botany of certain places in the Waikato District, April and May 1870. Transactions and Proceedings of the N.Z. Institute 3: 142-147.

Leamy, M. L., Milne, J. D. G., Pullar, W. A., and Bruce, J. G., 1973. Paleopedology and soil stratigraphy in the New Zealand Quaternary succession. N.Z. Journal of Geology and Geophysics 16: $723-744$

Lees, C. M., 1986. Late Quaternary palynology of the southern Ruahine Range, North Island, New Zealand. N.Z. Journal of Botany 21: 315-329.

Lintott, W. H. and Burrows, C. J., 1973. A pollen diagram and macrofossils from Kettlehole Bog, Cass, South Island, New Zealand. N.Z. Journal of Botany 11: 269-282.

Lowe, D. J., 1985. Applications of impulse radar to continuous profiling of tephra-bearing lake sediments and peats: an initial evaluation. N.Z. Journal of Geology and Geophysics 28: 667-674.

- 1986. Controls on the rates of weathering and clay mineral genesis in airfall tephras: a review and New Zealand case study. In S. M. Colman and D. P. Dethier (Eds): Rates of chemical weathering of rocks and minerals, pp 265-330. Academic Press, Orlando, Florida.

-, 1988 . Stratigraphy, age, composition, and correlation of late Quaternary tephras interbedded with organic sediments in Waikato lakes, North Island, New Zealand. N.Z. Journal of Geology and Geophysics 31: 125-165.

Lowe, D. J., and Green, J. D., 1987. Origins and development of the lakes. In A. B. Viner (Ed.): Inland Waters of New Zealand. N.Z. D.S.I.R. Bulletin 241: 1-64.

Lowe, J. P., Lowe, D. J., Hodder, A. P. W. and Wilson, A. T., 1984. A tritium exchange method for obsidian hydration shell measurement. Isotope Geoscience 2: 351-363.

Macphail, M. K., 1980. Fossil and modern Beilschmiedia (Lauraceae) pollen in New Zealand. N.Z. Journal of Botany 18: 453-457.

Macphail, M. K., and McQueen, D. R., 1983. The value of New Zealand pollen and spores as indicators of Cenozoic vegetation and climates. Tuatara 26: 37-59.

Matheson, K. S., 1978. Moanatuatua - an ecological study of an oligotrophic, restiad bog, Waikato, New Zealand. Unpublished M.Sc. thesis, University of Waikato. 
Maunder, W. J., 1974. Climate and climatic resources of the Waikato, Coromandel, King Country regions. N.Z. Meteorological Service Miscellaneous Publication 115.

McCraw, J. D., 1967. The surface features and soil pattern of the Hamilton Basin. Earth Science Journal 1: 59-74.

- 1975. Quaternary airfall deposits of New Zealand. Royal Society of N.Z., Bulletin 13: 35-44.

McFadgen, B., 1985. Late Holocene stratigraphy of coastal deposits between Auckland and Dunedin, New Zealand. Journal of the Royal Society of N.Z. 15: 27-65.

McGlone, M. S., 1980. Forest fire following Holocene tephra fall. In R. Howorth, P. C. Froggatt, C. G. Vucetich and J. D. Collen (Eds): Proceedings of Tephra Workshop, June 30-July 1, 1980, pp. 80-86. Geology Department, Victoria University of Wellington, Publication 20.

- 1983a. The history of New Zealand lowland forest since the last glaciation. In $\mathrm{K}$. Thompson, A. P. W. Hodder, and A. S. Edmonds (Eds): Lowland forests in New Zealand: pp. 1-17. University of Waikato, Hamilton.

, 1983b. Holocene pollen diagrams, Lake Rotorua, North Island, New Zealand. Journal of the Royal Society of N.Z. 13: 53-65.

- 1983c. Polynesian deforestation of New Zealand: a preliminary synthesis. Archaeology in Oceania 18: 11-25

- 1985. Plant biogeography and the late Cenozoic history of New Zealand. N.Z. Journal of Botany 23: 723-749.

McGlone, M. S., and Bathgate, J. L., 1983. Vegetation and climate history of the Longwood Range, South Island, New Zealand. N.Z. Journal of Botany 21: 293-315.

McGlone, M. S., and Moar, N. T., 1977. The Ascarina decline and post-glacial climatic change. N.Z. Journal of Botany 15: 485-489.

McGlone, M. S., and Topping, W. W., 1977. Aranuian (post-glacial) pollen diagrams from the Tongariro region, North Island, New Zealand. N.Z. Journal of Botany 15: 749-760.

McGlone, M. S., Nelson, C. S., and Hume, T. M., 1978. Palynology, age and environmental significance of some peat beds in the Upper Pleistocene Hinuera Formation, South Auckland, New Zealand. Journal of the Royal Society of N.Z. 8: 385-393.

McGlone, M. S., Nelson, C. S., and Todd, A. J., 1984. Vegetation history and environmental significance of pre-peat and surficial peat deposits at Ohinewai, Lower Waikato lowland. Journal of the Royal Society of N.Z. 14: 233-244.

McIntyre, D. J., 1963. Pollen morphology of the New Zealand species of Myrtaceae. Transactions of the Royal Society of N.Z., Botany 2: 83-170.

McKellar, M. H., 1973. Dispersal of Nothofagus pollen in eastern Otago, South Island, New Zealand. N.Z. Journal of Botany 1: 305-310.

McKelvey, P. J., and Nicholls, J. L., 1957. A provisional classification of North Island forests. N.Z. Journal of Forestry 7: 84-101.

Mildenhall, D. C., 1979. Holocene pollen diagrams from Pauatahanui Inlet, Porirua, New Zealand. N.Z. Journal of Geology and Geophysics 22: 585-591.

Mildenhall, D. C., and Brown, L. J., 1987. An early Holocene occurrence of the mangrove Avicennia marina in Poverty Bay, North Island, New Zealand: its climatic and geological implications. N.Z. Journal of Botany 25: 281-294.

Milne, J. D. G., and Smalley, I. J., 1979. Loess deposits in the southern part of the North Island of New Zealand. Acta Geologica 22: 197-204.

Moar, N. T., 1971. Contributions to the Quaternary history of New Zealand flora 6. Aranuian pollen diagrams from Canterbury, Nelson and North Westland, South Island. N.Z. Journal of Botany 9: 80-145.

Neall, V. E., 1975. Climate-controlled tephra redeposition on Pouakai Ring Plain, Taranaki, New Zealand. N.Z. Journal of Geology and Geophysics 18: 317-326.

Nelson, C. S., Hendy, C. H., Jarrett, K., and Cuthbertson, A. M., 1985. Near-synchroneity of New Zealand alpine glaciations and Northern Hemisphere continental glaciations during the past 750 kyr. Nature 318: 361-363.

Nicholls, J. L., 1983. The extent and variability of native lowland forest. In K. Thompson, A.P.W. Hodder, and A.S. Edmonds (Eds): Lowland forests in New Zealand, pp. 79-92. University of Waikato, Hamilton. 
Norton, D. A., Herbert, J. W., and Beveridge, A. E., 1988. The ecology of Dacrydium cupressinum: a review. New Zealand Journal of Botany 26: 37-62.

Ogden, J., 1976. Notes on the influence of drought on the but lowlands. Proceedings of the N.Z. Ecological Society 1985. An introduction to plant demograph

trees. Neze Zealand Journal of Botany 23:
Pittock, A. B., and Salinger, M. J., 1983. The climatic optimum and a $\mathrm{CO}_{2}$ warmed earth: the Australasian region. In J. M. A. Chappell and A. Grindrod (Eds): Procedings of the first CLIMANZ Conference, Howman's Gap, Victoria, Australia, Feb 8-13, 1981: 122-125. Australian Academy of Science, Canberra.

Pocknall, D. T., Gregory, M. R., and Greig, D. A., 1989. Palynology of Core 80/20 and its implications to understanding Holocene sea level changes in the Firth of Thames, New Zealand. Journal of the Royal Society of N.Z. 19: 171-179.

Porter, S. C., 1975. Equilibrium line of late Quaternary glaciers in Zealand. Quaternary Research 5: 27-48.

Roberton, J. B. W., 1965. Maori Settlement of the Waikato District. Te Awamutu Historical Society Bulletin 2.

Sakai, A., Paton, D. M., and Wardle, P., 1981. Freezing resistance of trees of the south temperate zone, especially subalpine species of Australasia. Ecology 62: 563-570.

Salinger, M. J., 1984. New Zealand climate: The last 5 million years. In J. C. Vogel (Ed.): Late Cainozoic palaeoclimates of the Southern Hemisphere, pp. 131-150. A. A. Balkema, Rotterdam.

Schicker, K. P., 1987. Sediments and hydrodynamics of Lake Waahi, Huntly, New Zealand. Unpublished M.Sc. thesis, University of Waikato.

Soons, J. M., 1979. Late Quaternary environments in the central South Island of New Zealand. N.Z. Geographer 35: 16-23.

Stewart, R. B., and Neall, V. E., 1984. Chronology of palaeoclimatic change at the end of the last glaciation. Nature 311: 47-48.

Stuiver, M., and Pearson, G. W., 1986. High precisior scale, A.D. 1950-500 B.C. Radiocarbon 28: 805-838.

Suggate, R. P., 1965. The Late Pleistocene geology of the northern part of the South Island, New Zealand. N.Z. Geological Survey, Bulletin 77.

Suggate, R. P., and Moar, N. T., 1970. Revision of the chronology of the late Otira Glacial. Journal of Geology and Geophysics 13: 742-746.

Sutton, D. G., 1987. A paradigmatic shift in Polynesian prehistory: implications for New Zealand. N.Z. Journal of Archaeology 9: 135-155

Tavlor, N. H., and Pohlen, I. J., 1958. Soils of the Waikato Basin. Proceedings of the N.Z. Society of Soil Science 3: 27-30.

Thiede, J., 1979. Wind regimes over the late Quaternary southwest Pacific Ocean. Geology 7: $259-262$.

Veblen, T. T., and Stewart, G. H., 1982. On the conifer regeneration gap in New Zealand: the dynamics of Libocedrus bidwillii stands on South Island. Journal of Ecology 70: 413-436.

Vucetich, C. G., and Pullar, W. A., 1963. Ash beds and soils in the Rotorua district. Proceedings of the N.Z. Ecological Society 10: 65-72.

1969 Stratigraphy and chronology of late Pleistocene volcanic ash beds in central North Island, New Zealand. N.Z. Journal of Geology and Geophysics 12: 784-837.

Wardle, P., 1963. Evolution and distribution of the New Zealand flora as affected by Quaternary climates. N.Z. Journal of Botany 1: 3-17.

Willett, R. W., 1950. The New Zealand Pleistocene snowline climatic conditions and suggested biological effects. N.Z. Journal of Science and Technology 32B: 18-48.

Wilson, A. T., 1978. Glacial history of New Zealand and the Ross Dependency, Antarctica. In E. M. van Zinderen Bakker (Ed.): Antarctic glacial history and world palaeoenvironments, pp. 15-23. A. A. Balkema, Rotterdam.

Wilson, C. J. N., 1985. The Taupo eruption, New Zealand. II. The Taupo ignimbrite. Philosophical Transactions of the Royal Society, London A314: 229-310.

Received 13 December 1988; accepted 13 March 1989. 